\title{
Environmental impacts of chocolate production and consumption in the UK
}

DOI:

10.1016/j.foodres.2018.02.042

Document Version

Accepted author manuscript

Link to publication record in Manchester Research Explorer

\section{Citation for published version (APA):}

Konstantas, A., Jeswani, H., Stamford, L., \& Azapagic, A. (2018). Environmental impacts of chocolate production and consumption in the UK. Food Research International. https://doi.org/10.1016/j.foodres.2018.02.042

\section{Published in:}

Food Research International

\section{Citing this paper}

Please note that where the full-text provided on Manchester Research Explorer is the Author Accepted Manuscript or Proof version this may differ from the final Published version. If citing, it is advised that you check and use the publisher's definitive version.

\section{General rights}

Copyright and moral rights for the publications made accessible in the Research Explorer are retained by the authors and/or other copyright owners and it is a condition of accessing publications that users recognise and abide by the legal requirements associated with these rights.

\section{Takedown policy}

If you believe that this document breaches copyright please refer to the University of Manchester's Takedown Procedures [http://man.ac.uk/04Y6Bo] or contact uml.scholarlycommunications@manchester.ac.uk providing relevant details, so we can investigate your claim.

\section{OPEN ACCESS}




\title{
Environmental impacts of chocolate production and consumption in the UK
}

Antonios Konstantas, Harish K. Jeswani, Laurence Stamford and Adisa Azapagic*

Sustainable Industrial Systems, School of Chemical Engineering and Analytical Science, The University of Manchester, The Mill, Sackville Street, Manchester M13 9PL, UK

${ }^{*}$ Corresponding author: adisa.azapagic@manchester.ac.uk

\begin{abstract}
This study evaluates life cycle environmental impacts associated with chocolate products made and consumed in the UK. The paper focuses on three representative chocolate products occupying $90 \%$ of the market: 'moulded chocolate', 'chocolate countlines' and 'chocolates in bag'. The impacts were estimated using life cycle assessment (LCA) as a tool and following the ReCiPe impact assessment method. The water footprint was also considered. For example, the global warming potential ranges between $2.91-4.15 \mathrm{~kg} \mathrm{CO}$ eq., primary energy demand from 30-41 MJ and the water footprint, including water stress, from 31-63 I per kilogram of chocolate. The raw materials are the major hotspot across all impact categories for all three product types, followed by the chocolate production process and packaging. The raw material impacts are mainly due to milk powder, cocoa derivatives, sugar and palm oil. The sensitivity analysis shows that the results for global warming potential are sensitive to land-use change (LUC) associated with cocoa production, increasing the impact of the chocolate products by three to four times if LUC is involved. The improvement opportunities targeting the key contributing stages suggest that GWP of chocolates could be reduced by $14 \%-19 \%$. Chocolate countlines have the highest contribution to the total impacts at the UK level $(37 \%-43 \%)$, followed by chocolates in bag $(28 \%-33 \%)$. Moulded chocolates and other chocolate confectionary make up the rest of the impacts, with a roughly equal share each. Chocolate consumption in the UK contributes $4.7 \%$ to the primary energy consumption and $2.4 \%$ to the GHG emissions from the whole food and drink sector. The results of this work will be of interest to policy makers, chocolate producers and consumers, helping them to make more informed decisions towards sustainable production and consumption of chocolate products.
\end{abstract}

Keywords: Chocolate; climate change; environmental sustainability; life cycle assessment; food supply chains

\section{Introduction}

Chocolate products are the most widespread desserts and snacks around the globe (ICCO, 2016). They are made from cocoa beans obtained from the tree Theobroma cacao, an indigenous tree to South America (Afoakwa, 2016). Cocoa was firstly cultivated by the Aztecs while the Spanish were the first to bring its beverage to Europe in the 15th century (Afoakwa, 2016). At that time, chocolate was very expensive and its consumption was reserved for the wealthier social classes in Europe. Later on, with addition of milk and sugar as well as due to the breakup of the cocoa monopoly, chocolate became more popular (Beckett, 2009). The use of cocoa to produce diverse and industrialised products began in the UK in the $19^{\text {th }}$ century where the first plain chocolate bars were produced (Beckett, 2009).

Cocoa is mainly cultivated around the equator in humid climate conditions. Cote D'Ivoire, Ghana, Indonesia, Nigeria, Ecuador and Brazil are the major producers and exporters of cocoa beans (ICCO, 2016). According to ICCO (2016), the annual production of cocoa beans in 2016 was 4.25 million tonnes. The worldwide sales of chocolate were estimated to be worth more than US $\$ 101$ billion in 2015 (Statista, 2015) with Europe accounting for 45\% of the global consumption (Afoakwa, 2016). Chocolate products are also very popular in the UK - with an estimated consumption of $7.9 \mathrm{~kg} /$ person (Afoakwa, 2016), the country ranks the sixth highest chocolateconsuming country in the world (Caobisco, 2015).

The UK chocolate confectionary sector, which was worth $£ 4.34$ billion in 2014 , grew by $16.4 \%$ and is expected to grow by a further $8.8 \%$ by 2019 (Key Note, 2015). The sector is divided into four categories: i) chocolate countlines; ii) sharing bags and boxed chocolates ('chocolates in bag'); iii) 
blocks and moulded bars ('moulded chocolates'); and iv) other chocolate confectionary goods. The first three categories account for more than $90 \%$ of the total sales volume, most of which are milkbased products as dark chocolate is not very popular in the UK. As shown in Fig. 1, chocolate countlines dominate the market with the share of $41.8 \%$, followed by chocolates in bag (30\%) and moulded chocolates (19.5\%). The remaining $8.7 \%$ are other chocolate confectionary products which include seasonal products, such as those sold during Christmas and Easter, and various "novelty" products (Key Note, 2015).

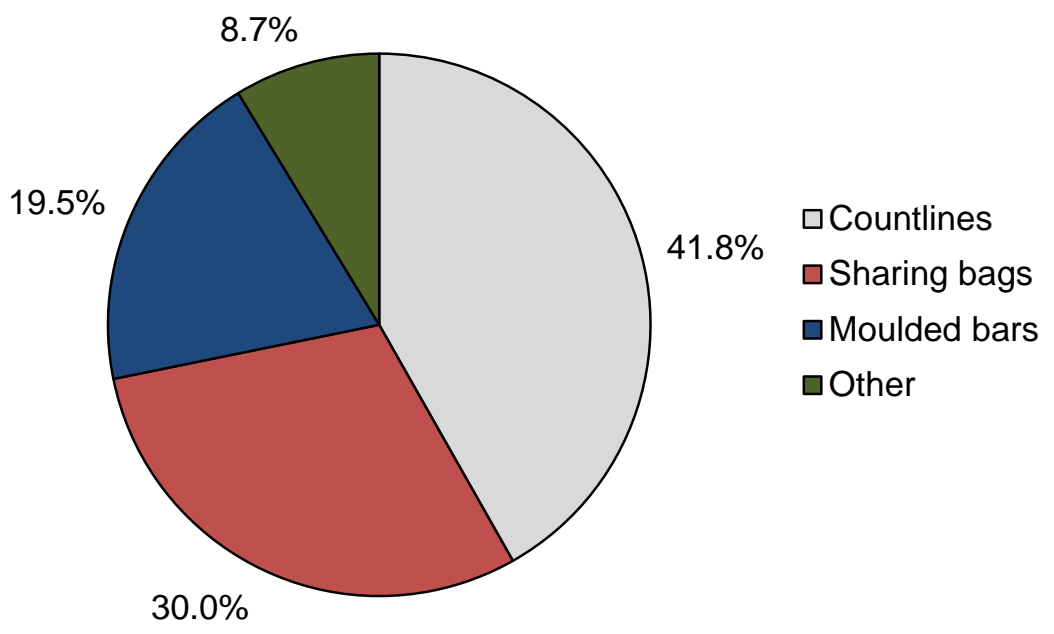

Fig. 1. Breakdown of the chocolate confectionary sector in the UK by market value (Key Note, 2015)

So far, there have been few other studies of environmental impacts of chocolates. Most of these focused on dark chocolate, with two studies based in Italy (Recanati et al., 2018; Vesce et al., 2016), one in Ecuador (Perez Neira, 2016) and one in Europe in general (Busser \& Jungbluth, 2009). The last also considered milk chocolate in aluminium packaging. All the studies followed the life cycle of chocolate from cradle to grave, apart from that by Vesce et al. (2016) which was a gate-to-gate study. Unlike the previous studies which concentrated on individual chocolate products, this paper considers a range of chocolate confectionary products to evaluate environmental impacts of chocolate production and consumption in the UK. The next section provides details on the product categories considered and gives an overview of the methodology used to evaluate the environmental impacts.

\section{Methodology}

Life cycle assessment (LCA) was used to estimate the impacts of chocolate products, following the ISO 14040/14044 guidelines (ISO, 2006a\&b). The methodology, data and the assumptions are described in more detail in the following sections.

\subsection{Goal and scope}

The goal of the study is to assess the environmental impacts of production and consumption of chocolate products in the UK. The study considers the following market-leading products in each of the three main sub-sectors (Mintel, 2015): chocolate coated wafers (chocolate countlines), milk chocolate (moulded chocolate) and malty chocolates (chocolates in bag). The impacts are first assessed at the product level with the functional unit defined as ' $1 \mathrm{~kg}$ of packaged chocolate consumed at home'. The second part of the study considers the annual impacts of chocolate consumption in the UK for which the functional unit is the 'annual consumption of chocolates in the UK'.

As outlined in Fig. 2, the system boundary is from cradle to grave, comprising the following stages: 
- Raw materials (ingredients): production of sugar, milk powder, cocoa butter, vegetable fat, cocoa mass, flour, pasteurised eggs, salt, butter, whey powder and starch.

- Manufacturing: electricity, steam and water consumption in the manufacturing processes, including cleaning activities.

- Packaging: aluminium foil (primary), corrugated-boxes and stretch film (secondary and tertiary).

- Distribution and consumption: storage in a regional distribution centre and at retailer, and consumption at home.

- Waste management: treatment and disposal of process and post-consumer waste.

- Transport: transport of raw materials and packaging to the production facility, product and waste transport along the life cycle.

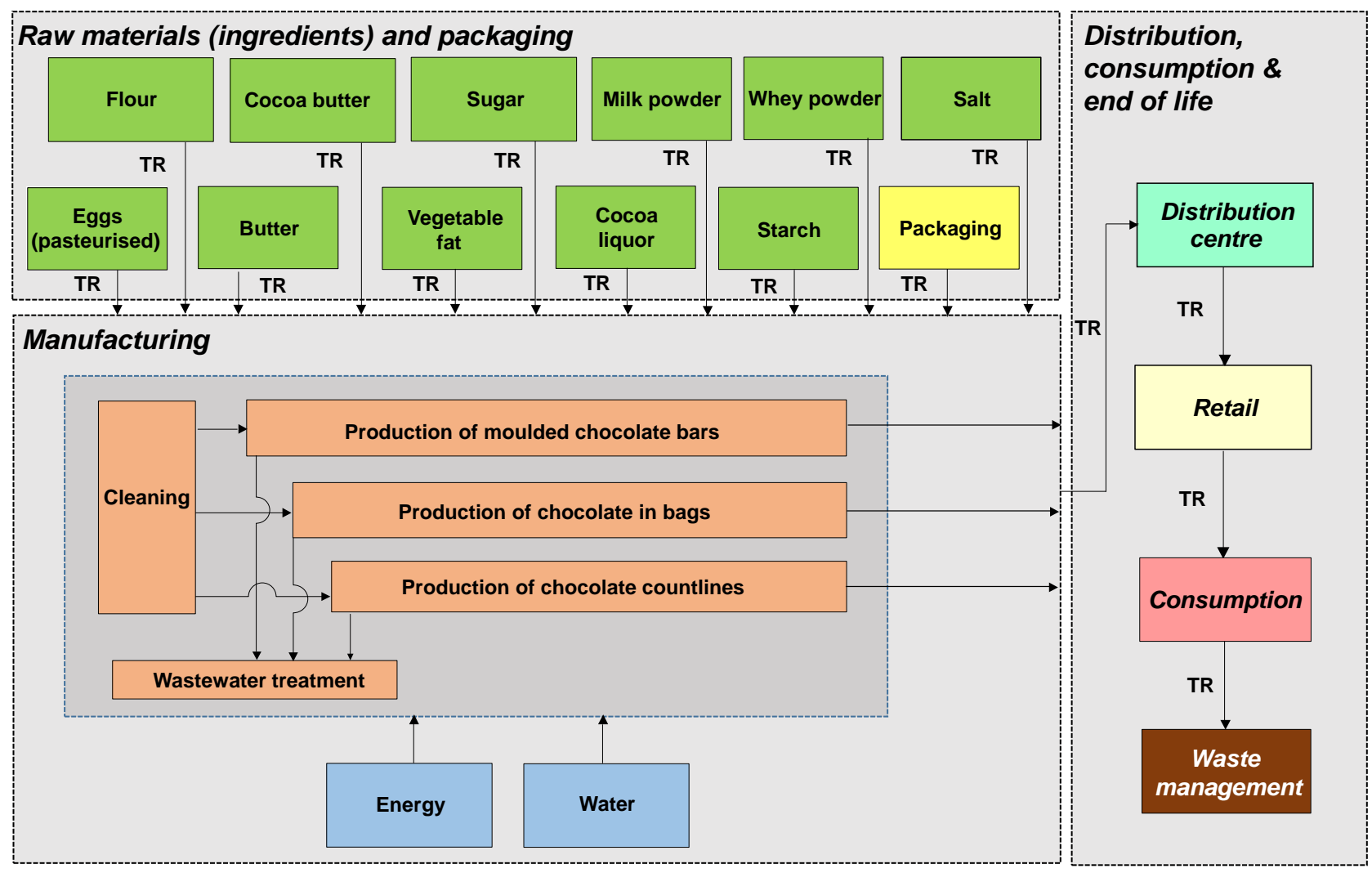

Fig. 2. Life cycle stages of chocolate products considered in the study

[TR: transport]

\subsection{Inventory data and assumptions}

The foreground data were sourced from publically available information provided by manufacturers and from the literature. The background life cycle inventory $(\mathrm{LCl})$ data were obtained from Ecoinvent V2.2 (Ecoinvent, 2010). Any data gaps were filled using Ecoinvent V3.3 (Ecoinvent, 2016) and the GaBi database (Thinkstep AG, 2016) as detailed further below.

\subsubsection{Raw materials (ingredients)}

The main ingredients for all chocolate types are sugar, milk powder, cocoa butter and cocoa liquor; however, their composition varies among the considered products as shown in Table 1. The data sources and key assumptions for these ingredients are described below.

Milk powder is produced from UK raw milk. The milk production was modelled using data from the Scottish Government (2011) study. The data on energy consumption for milk processing and milk powder production were obtained from Brush et al. (2011). The cleaning activities in the milkpowder manufacturing facility were modelled according to DeJong (2013) and Hogaas (2002), while wastewater quantities and its onsite treatment are based on data from Envirochemie (2016) and Ecoinvent (2010), respectively. 
Table 1 Ingredients of chocolate products (Beckett, 2009).

\begin{tabular}{|c|c|c|c|}
\hline Ingredient & $\begin{array}{l}\text { Milk chocolate } \\
(\%)\end{array}$ & $\begin{array}{l}\text { Chocolate } \\
\text { countlines }^{a} \\
(\%)\end{array}$ & $\begin{array}{l}\text { Chocolates in } \\
\text { bag }^{\text {b }} \\
(\%)\end{array}$ \\
\hline \multicolumn{4}{|l|}{ Sugar } \\
\hline in milk chocolate & 45 & 29.70 & 32.85 \\
\hline in wafers & & 8.33 & \\
\hline in white chocolate & & & 4.81 \\
\hline in malted milk powder & & & 4.66 \\
\hline \multicolumn{4}{|l|}{ Milk powder } \\
\hline in milk chocolate & 24.5 & 16.17 & 17.89 \\
\hline in white chocolate & & & 4.29 \\
\hline in malted milk powder & & & 4.66 \\
\hline \multicolumn{4}{|l|}{ Cocoa butter } \\
\hline in milk chocolate & 17 & 11.22 & 12.41 \\
\hline in white chocolate & & & 3.90 \\
\hline Vegetable fat & 5 & 3.30 & 3.65 \\
\hline Cocoa liquor & 8 & 5.28 & 5.84 \\
\hline Emulsifiers $^{c}$ & 0.5 & 0.33 & 0.37 \\
\hline \multicolumn{4}{|l|}{ Flour } \\
\hline in wafers & & 11.56 & \\
\hline in malted milk powder & & & 2.34 \\
\hline Eggs (pasteurised) & & 0.24 & \\
\hline Salt & & 0.07 & \\
\hline Water & & 13.33 & \\
\hline Butter & & 0.24 & \\
\hline Whey powder & & 0.24 & \\
\hline Starch & 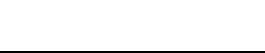 & & 2.34 \\
\hline
\end{tabular}

The production of milk butter and whey powder is based on Ecoinvent V3.3 data while the evaporation process was modelled based on Westergaard (2010). The LCl data for these two ingredients were sourced from Ecoinvent V3.3 as they were not available in Ecoinvent V2.2. However, the raw milk production and the energy mix were modified to correspond to the UK conditions by replacing the corresponding data in the Ecoinvent V3.3 inventory.

Cocoa butter and cocoa liquor are produced in the UK from cocoa beans cultivated in West Africa. The environmental profiles of these cocoa products are based on Ntiamoah and Afrane (2008) as adopted in the product environmental footprint (PEF) data in EC (2015a). The land-use change was not considered in the base case but its effect on the impacts was explored through a sensitivity analysis. Economic allocation was used for the cocoa co-products based on their market prices; the influence of mass allocation was also considered in the sensitivity analysis.

Wheat is cultivated in the UK and milled to produce flour, the main ingredient for manufacturing malted milk powder. The milling process was modelled using data from EC (2015b), Manley (2000) and Ecoinvent (2010), while wheat LCl data were obtained from the AgriLCA model (Audsley et al., 2009), Ecoinvent (2010) and the Agri-footprint database (Blonk, 2015). Economic allocation was used for allocating the impacts between the flour and the bran.

Barley was assumed to be the main ingredient for producing starch. Starch was modelled using data from EC (2015c), Ecoinvent (2010) and the AgriLCA model (Cranfield University, 2005) for barley cultivation in the UK.

Pasteurised eggs were modelled using egg production data from the PROBAS database (UBA, 2016) and pasteurisation process according to EC (2015b). It was assumed that $40 \%$ of sugar is produced from locally cultivated sugar beet and the rest from the imported sugar cane. Sugar was modelled using Ecoinvent (2010) data. Palm oil was assumed to be the main source for the 
vegetable fat and the LCl data were obtained from the Ecoinvent (2010) and GaBi (Thinkstep AG, 2016) databases.

\subsubsection{Manufacturing}

This section describes the manufacturing processes for producing chocolates. The data on energy consumption across all individual processes are detailed in Table 2.

Table 2 Production processes and associated energy consumption.

\begin{tabular}{lccl}
\hline $\begin{array}{l}\text { Processes and } \\
\text { activities }\end{array}$ & $\begin{array}{l}\text { Natural gas } \\
\text { (MJ per kg } \\
\text { material } \\
\text { processed) }\end{array}$ & $\begin{array}{l}\text { Electricity } \\
\text { (MJ per kg } \\
\text { material } \\
\text { processed) }\end{array}$ & Data sources \\
\hline Mixing & & Hamburger \& Dresdner (2016) \\
$\quad$ Ingredients for chocolate & & 0.0211 & Brush et al. (2011) \\
$\begin{array}{l}\text { Ingredients for wafers } \\
\text { Refining }\end{array}$ & 0.113 & Hamburger \& Dresdner (2016) \\
Conching & 0.132 & Hamburger \& Dresdner (2016) \\
Tempering & 0.13 & Hamburger \& Dresdner (2016) \\
Moulding & 0.0135 & Brush et al. (2011) \\
Cooling & 0.187 & Brush et al. (2011) \\
Packing & 0.36 & Brush et al. (2011) \\
Cleaning & 0.364 & \\
For moulded chocolate bars & & & UBA (2016) \\
For chocolate countlines & & 0.364 & UBA (2016) \\
$\quad$ For chocolates in bag & 0.63 & UBA (2016) \\
Shaping & 0.18 & Brush et al. (2011) \\
Baking & 0.303 & Brush et al. (2011) \\
Enrobing & & Brush et al. (2011) \\
Panning & 0.28 & Hamburger \& Dresdner (2016) \\
\hline
\end{tabular}

The production of milk chocolate involves mixing of ingredients, refining, conching, tempering and moulding (Beckett, 2009). Afterwards, the chocolate bars are cooled and packaged. A slightly different production method is followed for producing the chocolate countlines, which includes two separate production lines. The first encompasses producing wafers, which involves mixing of ingredients, shaping, baking and cooling processes (Manley, 2001). The second is identical to that used for producing milk chocolate. In the next step, wafers are enrobed with chocolate, cooled and packed. The manufacturing of the chocolates in bag involves the production of milk chocolate, white chocolate and malted milk powder. White chocolate is produced in the same way as milk chocolate, which is then panned with the malted milk powder. The panned mix is coated with milk chocolate, cooled and packed.

The energy use associated with the chocolate mixing, refining, conching, tempering and panning processes was obtained from the Hamburg \& Dresdner machine factories (2016) while for the other production processes the data were obtained from Berkley Energy Laboratory (Brush et al., 2011). The energy for cleaning activities was calculated as $10 \%$ of the total facility demand (UBA, 2016).

\subsubsection{Packaging}

The chocolate products are packaged into aluminium foil (primary packaging), which are then packed into corrugated-board boxes (secondary packaging) that are wrapped in low density polyethylene (LDPE) film (tertiary packaging). The amount of the primary packaging materials used for the chocolate products was obtained by weighing the packaging for the representative products. The amount of secondary material was evaluated after weighing and allocating it to $1 \mathrm{~kg}$ of the respective product (the functional unit). Tertiary packaging materials were obtained from the literature (EC 2016a). Consumer plastic bags were also considered. The data for the packaging of the products are given in

Table 3. 
Table 3 Inventory data for packaging.

\begin{tabular}{lccc}
\hline Packaging & $\begin{array}{c}\text { Milk chocolate } \\
\mathbf{( g / \mathbf { k g } )}\end{array}$ & $\begin{array}{c}\text { Chocolate } \\
\text { countlines } \\
\mathbf{( g / \mathbf { k g } )}\end{array}$ & $\begin{array}{c}\text { Chocolates } \\
\text { in bag } \\
\mathbf{( g / k g})\end{array}$ \\
\hline Aluminium foil (primary packaging) & 15 & 25.3 & 39.8 \\
Cardboard (secondary packaging) & 68.4 & 56.6 & 137 \\
LDPE $^{\mathrm{a}}$ (tertiary packaging) & 0.47 & 0.47 & 0.47 \\
LDPE $^{\mathrm{a}}$ (consumer plastic bags) & 2.4 & 2.5 & 3.5 \\
\hline
\end{tabular}

${ }^{\mathrm{a}}$ Low density polyethylene

The production of the packaging materials was modelled using inventory data from Ecoinvent (2010) and EAA (2013). Aluminium foil is produced from an aluminium mix which was assumed to contain 32\% secondary aluminium (Classen, et al., 2009). Corrugated-board was modelled according to data in Hirshier (2007) and assuming 78\% recycled content. Finally, tertiary packaging and consumer plastic bags were modelled using Ecoinvent (2010) data assuming use of LDPE packaging film.

\subsubsection{Distribution and retail}

It was assumed that the products are stored for four weeks in distribution centres and two weeks in supermarkets at an ambient temperature. Electricity consumption for ambient storage and water use were estimated in accordance with EC (2016a).

\subsubsection{Waste management}

All relevant solid and liquid waste streams associated with the production processes, distribution and post-consumption stages were considered (Table 4). It was assumed that solid process waste, which includes $2 \%$ losses of ingredients, is composted and that wastewater is treated before discharge. The waste disposal routes for other waste streams were assumed as per the current waste management practices in the UK (EC, 2016b,c). In accordance with ISO 14044 (ISO, $2006 \mathrm{~b})$, the system was credited for energy recovery, composting and aluminium recycling.

Table 4 Inventory data for the process and post-consumer waste management activities

\begin{tabular}{|c|c|c|c|c|}
\hline $\begin{array}{l}\text { Type of waste and } \\
\text { treatment }\end{array}$ & $\begin{array}{c}\text { Milk } \\
\text { chocolate } \\
(\mathrm{g} / \mathrm{kg})\end{array}$ & $\begin{array}{c}\text { Chocolate } \\
\text { countlines } \\
(\mathrm{g} / \mathrm{kg})\end{array}$ & $\begin{array}{c}\text { Chocolates } \\
\text { in bag } \\
(\mathrm{g} / \mathrm{kg})\end{array}$ & Sources of LCA data \\
\hline $\begin{array}{l}\text { Wastewater }{ }^{\mathrm{a}} \\
\text { (onsite treatment) }\end{array}$ & 2700 & 2700 & 2700 & $\begin{array}{l}\text { Modelled using data from Ecoinvent } \\
(2010)\end{array}$ \\
\hline $\begin{array}{l}\text { Process losses } \\
\text { composting }\end{array}$ & 20 & 20 & 20 & Ecoinvent $(2010)$ \\
\hline $\begin{array}{l}\text { Corrugated } \\
\text { cardboard }^{c}\end{array}$ & 68.4 & 56.6 & 137 & $\begin{array}{l}86.5 \% \text { recycling and } 13.5 \% \text { incineration } \\
\text { with energy recovery }(E C, 2016 c)\end{array}$ \\
\hline $\begin{array}{l}\text { Aluminium } \\
\text { packaging }^{d}\end{array}$ & 15 & 25.3 & 39.8 & $\begin{array}{l}\text { Aluminium recycling rate: } 41.8 \% \text { (EC, } \\
2016 \mathrm{~b}) \text {; the rest is landfilled. }\end{array}$ \\
\hline Plastic waste & & & & $58 \%$ landfill, 34\% incineration with \\
\hline Tertiary packaging & 0.47 & 0.47 & 0.47 & energy recovery and $8 \%$ incineration \\
\hline Plastic bags & 2.4 & 2.5 & 3.5 & without energy recovery (EC, $2016 b)$. \\
\hline \multicolumn{5}{|c|}{$\begin{array}{l}\text { Due to a lack of data on the amount of wastewater in the chocolate industry, the equivalent of a UK based confectionary } \\
\text { manufacturer was used. } \\
\text { Losses in the manufacturing processes were assumed at } 2 \% \text {. } \\
\text { The efficiency of the corrugated-board recycling process is } 90 \% \text { (Ecoinvent, 2010). } \\
\text { The efficiency of the aluminium recycling process is } 96 \% \text { (EAA, 2013). }\end{array}$} \\
\hline
\end{tabular}




\subsubsection{Transport}

Table 5 details transport distances and modes as well as the place of origin of the transported goods. Road distances were obtained from EC (2016a) in accordance with the Eurostat transport data while sea transport distances were estimated using the Searates (2016) route calculator. Where data were not available, assumptions were made in accordance with EC (2016a).

Table 5 Transportation means and distances

\begin{tabular}{|c|c|c|c|c|}
\hline Life cycle stage & Transport step & Country of origin & $\begin{array}{l}\text { Transportation } \\
\text { means }\end{array}$ & $\begin{array}{c}\begin{array}{c}\text { Distance } \\
(\mathbf{k m})\end{array} \\
\end{array}$ \\
\hline \multirow[t]{13}{*}{ Raw materials } & Sugar from sugar beet & UK & Lorry (16-32 t) & $200^{a}$ \\
\hline & Sugar from sugar cane & & & \\
\hline & by road & Brazil & Lorry (16-32 t) & $500^{\mathrm{a}}$ \\
\hline & by sea & Brazil to UK & Freight ship & 9650 \\
\hline & by road & UK & Lorry (16-32 t) & 200 \\
\hline & Palm/ Palm kernel oil & & & \\
\hline & by sea & Malaysia to UK & Freight ship & 15,900 \\
\hline & by road & UK & Lorry $(16-32 \mathrm{t})$ & 200 \\
\hline & Cocoa beans & & & \\
\hline & by road & Ghana & Lorry (16-32 t) & $500^{a}$ \\
\hline & by sea & Ghana to UK & Freight ship & 7370 \\
\hline & by road & UK & Freight ship & 200 \\
\hline & All other ingredients & UK & Freight ship & 200 \\
\hline Manufacturing & Manufacturer to distribution centre & UK & Lorry $16-32 \mathrm{t}$ & $150^{\mathrm{a}}$ \\
\hline Distribution centre & Distribution centre to retailer & UK & Lorry $3.5-7.5 \mathrm{t}$ & 200 \\
\hline \multirow[t]{2}{*}{ Packaging } & Packaging to manufacturer & UK & Lorry (16-32 t) & $200^{d}$ \\
\hline & Plastic bags to retailer & UK & Lorry (16-32 t) & 200 \\
\hline Consumption & Retailer to consumer & UK & $\mathrm{Car}^{\mathrm{a}}$ & $0.135^{\mathrm{b}}$ \\
\hline \multirow[t]{3}{*}{ End of life } & Waste to recycling & UK & Lorry $(7.5-16 \mathrm{t})$ & 100 \\
\hline & Waste to landfill & UK & Lorry $(21 \mathrm{t})$ & $30^{\mathrm{c}}$ \\
\hline & Waste to incineration & UK & Lorry $(21 \mathrm{t})$ & $30^{\mathrm{c}}$ \\
\hline
\end{tabular}

a Source: EC (2016a).

${ }^{\mathrm{b}}$ Distance assigned to the functional unit considering $6.4 \mathrm{~km}$ roundtrip divided by $28 \mathrm{~kg}$ consumer basket and $59 \%$ of distance travelled by car (Pretty at al., 2005).

${ }^{\mathrm{c}}$ Distance for transporting waste to landfill/incineration plant.

\subsection{Impact assessment}

GaBi V6.4 software (Thinkstep, 2016) was used to model the system and the ReCiPe midpoint method (Goedkoop et al., 2013) was applied to estimate the environmental impacts. The following impact categories were considered: Global warming potential (GWP), ozone depletion (OD), fossil fuel depletion (FFD), freshwater eutrophication (FE), marine eutrophication (ME), human toxicity $(\mathrm{HT})$, terrestrial ecotoxicity (TET), freshwater ecotoxicity (FET), marine ecotoxicity (MET), terrestrial acidification (TA), Agricultural land occupation (ALO), urban land occupation (ULO), natural land transformation (NLT), photochemical oxidant formation (POF) and mineral depletion (MD).

Furthermore, primary energy demand (PED), volumetric water consumption and water footprint were also estimated. PED was estimated using GaBi software. The volumetric water consumption was quantified taking into account blue and green water, following the approach developed by Hoekstra et al. (2011) and using data provided by the Water Footprint Network (2016). The water footprint was estimated following the approach by Pfister et al. (2009), taking into account water stress in different regions; this approach considers only blue water. The WF was estimated using CCaLC (2015) software and database. 


\section{Results and discussion}

The results are presented in Fig. 3 and Tables S-1 and S-2 in the Supplementary information (SI) and are discussed for each impact in turn below.

\subsection{Environmental impacts}

Primary energy demand (PED): As shown in Fig. 3a, chocolates in bag have the highest PED, which is estimated at $40 \mathrm{MJ} / \mathrm{kg}$ while the other two products consume $30 \mathrm{MJ} / \mathrm{kg}$. For all three products, the majority of the impacts are associated with the production of raw materials (49\%$66 \%)$. Milk powder $(31 \%-47 \%)$ is the main contributor to PED used for the production of raw materials. Other activities that significantly contribute to energy consumption are the manufacturing processes and the primary packaging. For the chocolate countlines, manufacturing accounts for $26 \%$ of the total and for chocolates in bag, packaging contributes $21 \%$.

Global warming potential (GWP): The GWP of the chocolate products shows a similar trend as the PED (Fig. 3b). Chocolates in bag have the highest impact $(4.15 \mathrm{~kg} \mathrm{CO} 2$ eq. $/ \mathrm{kg}$ ), followed by moulded chocolate $(3.39 \mathrm{~kg} \mathrm{CO}$ eq. $/ \mathrm{kg}$ ) and chocolate countlines $(2.91 \mathrm{~kg} \mathrm{CO} 2 \mathrm{eq} . / \mathrm{kg}$ ). The contribution analysis shows that production of the raw materials is the major hotspot, accounting for $67 \%-81 \%$ of the total impact. Similar to PED, milk powder is responsible for most of the GWP related to the raw materials. Manufacturing is also an important contributor $(8 \%-16 \%)$ while packaging has a notable share for chocolate countlines and chocolates in bag $(8 \%-13 \%)$. Its contribution for moulded chocolate is lower (8\%). These results exclude land-use change for cocoa beans cultivation which is considered in the sensitivity analysis (see section 3.3.2).

Fossil fuel depletion (FFD): Fossil fuel depletion ranges from 24-31 MJ/kg (Fig. 3c), with chocolates in bag having the highest impact and the other two product depleting a similar amount of resources (23 and $24 \mathrm{MJ} / \mathrm{kg}$ ). The main hotspots are milk powder $(33 \%-48 \%)$, chocolate production (13\%-26\%) and packaging (7\%-21\%).

Ozone depletion (OD): The chocolates in bag have the highest and the countlines the lowest OD: 206 and $148 \mu \mathrm{g} \mathrm{CFC-11} \mathrm{eq./kg,} \mathrm{respectively} \mathrm{(Fig.} \mathrm{3d).} \mathrm{The} \mathrm{impact} \mathrm{from} \mathrm{the} \mathrm{moulded} \mathrm{chocolate} \mathrm{is}$ $170 \mu \mathrm{g} \mathrm{CFC}-11 \mathrm{eq} / \mathrm{kg}$. The most relevant life cycle stages are the raw materials $(61 \%-71 \%)$, transport $(13 \%-15 \%)$ and packaging $(9 \%-22 \%)$. The production of milk powder, sugar, cocoa butter and cocoa powder are the highest contributing processes within the raw materials stage (Table S-2). The vast majority of OD is caused by halogenated organic emissions from these stages.

Freshwater eutrophication (FE): As shown in Fig. 3e, chocolates in bag are the worst option with respect to FE $(0.87 \mathrm{~g} \mathrm{P}$ eq. $/ \mathrm{kg})$; the other two products have nearly equal FE $(0.64 \mathrm{~g} \mathrm{P}$ eq. $/ \mathrm{kg})$. The majority of the impact (57\%-72\%) is associated with the production of key ingredients, such as milk powder, sugar, flour and cocoa butter (Table S-2). The contribution of manufacturing and packaging is also significant, ranging between $12 \%-21 \%$ and $12 \%-29 \%$, respectively.

Marine eutrophication (ME) is similar for milk chocolate and chocolates in bag (10-11 N eq. $/ \mathrm{kg}$ ), whereas chocolate countlines have a $30 \%$ lower impact (Fig. 3f). The ME is almost entirely due to the raw materials production $(97 \%-99 \%)$, with milk powder and sugar being the main contributors. This is largely due to nitrate $(74 \%)$ and ammonia emissions $(20 \%-21 \%)$ to marine water.

Human toxicity (HT) ranges from $1.66 \mathrm{~kg} \mathrm{1,4} \mathrm{DCB} \mathrm{eq./kg} \mathrm{for} \mathrm{the} \mathrm{countlines} \mathrm{to} 2.03 \mathrm{~kg} 1,4 \mathrm{DCB}$ eq./kg for chocolates in bag (Fig. $3 \mathrm{~g}$ ). The majority of the impact is related to the raw materials $(77 \%-85 \%)$, specifically milk powder and sugar; in the case of chocolate countlines, flour also has a significant impact share (14\%). HT is mainly due to the emissions of phosphorus $(42 \%-48 \%)$ and manganese $(16 \%-17 \%)$, followed by zinc $(9 \%)$ and chlorine $(6 \%)$.

Terrestrial ecotoxicity (TET): Moulded and chocolates in bag have the highest TET, estimated at 31 and $30 \mathrm{~g} \mathrm{1,4-DCB} \mathrm{eq./kg}$, respectively, while that of the chocolate countlines is equal to $23 \mathrm{~g}$ $1,4-\mathrm{DCB}$ eq./kg (Fig. $3 \mathrm{~h})$. The raw materials cause the majority of this impact (90\%-92\%), with the rest attributed to transport (7\%-9\%). Milk powder, sugar, palm oil and cocoa butter are the most 
significant contributors among the raw materials (Table S-2). TET is mainly due to pesticides $(69 \%)$ used in the agriculture, followed by chlorine $(15 \%-17 \%)$ and copper $(5 \%-6 \%)$ released along the life cycle.

Freshwater ecotoxicity (FET): As indicated in Fig. 3i, FET is highest for milk chocolate $(133 \mathrm{~g} \mathrm{1,4-}$ DCB eq. $/ \mathrm{kg})$, followed closely by chocolates in bag (131 g 1,4-DCB eq. $/ \mathrm{kg})$. The impact from the countlines is around $25 \%$ lower (101 g 1,4-DCB eq. $/ \mathrm{kg})$. Like TET, the main cause of this impact are the raw materials $(91 \%-96 \%)$, with more than a half associated with cocoa cultivation. Milk powder (19\%-21\%) and sugar (11\%) also have noteworthy contributions. FET can be traced back to copper, zinc and phosphorus releases as well as to pesticides used in agriculture.

Marine ecotoxicity (MET): Milk chocolate has the highest MET, followed by chocolates in bag, estimated at 121 and $117 \mathrm{~g} \mathrm{1,4-DCB} \mathrm{eq./kg,} \mathrm{respectively.} \mathrm{By} \mathrm{comparison,} \mathrm{chocolate} \mathrm{countlines}$ have an impact of $89 \mathrm{~g} / \mathrm{kg}$ (Fig. 3j). Like the other two ecotoxicity impacts, MET is mainly due to the raw materials (87\%-93\%), of which more than $50 \%$ is also associated with cocoa production. Copper and zinc releases are the main environmental burdens causing this impact.

Terrestrial acidification (TA): As can be seen in Fig. 3k, the lowest TA was estimated for the countlines (46 $\mathrm{g} \mathrm{SO}_{2}$ eq. $/ \mathrm{kg}$ ) and the highest for chocolates in bag $\left(72 \mathrm{~g} \mathrm{SO}_{2} \mathrm{eq} . / \mathrm{kg}\right)$, with the impact of moulded chocolates in between $\left(65 \mathrm{~g} \mathrm{SO}_{2}\right.$ eq. $\left./ \mathrm{kg}\right)$. The raw materials are again the main hotspot $(92 \%-96 \%)$, with the milk powder production contributing most of it (89\%-90\%). The main environmental burdens are emissions of ammonia (84\%-87\%), nitrogen oxides $(5 \%-7 \%)$ and sulphur dioxide $(7 \%-9 \%)$.

Land use and transformation: Three types of land were considered: agricultural, urban and natural. Chocolates in bag have the highest and the countlines the lowest impacts on land across the three types (Fig. 3l-n). As expected, the impact on agricultural and natural land is largely due to the cultivation of raw materials (71\%-99\%). Milk powder contribute most to the land use and transformation, followed by sugar (Table S-2). This is due to the land occupation for pastures $(50 \%-57 \%)$ and for arable land (38\%-44\%); urban land occupation is mainly related to industrial buildings and roads network.

Photochemical oxidant formation (POF): Chocolates in bag have the highest POF (13 $\mathrm{g} \mathrm{NMVOC}$ eq. $/ \mathrm{kg}$ ) while the impacts of the other two products are slightly lower $(9-11 \mathrm{~g} \mathrm{NMVOC} \mathrm{eq./kg).} \mathrm{As}$ can be inferred from Fig. 3o, the raw materials contribute $70 \%-79 \%$ to the total and transport $9 \%-$ $11 \%)$; for chocolates in bag, the share of packaging is also significant (15\%). The most relevant activities for POF are milk powder (33\%-42\%) and sugar (19\%-22\%). The main POF burdens are emissions of nitrogen oxides $(57 \%-59 \%)$, carbon monoxide $(14 \%-17 \%)$ and non-methane volatile organic compounds (9\%).

Mineral depletion (MD): Mineral depletion is depicted in Fig. 3p showing that chocolates in bag

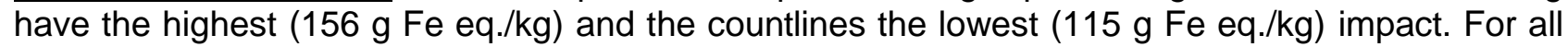
three types of chocolate, this is mainly due to the raw materials $(71 \%-88 \%)$, followed by manufacturing $(7 \%-13 \%)$ and packaging $(7 \%-17 \%)$. Among the raw materials, cocoa butter and liquor together contribute more than a third and the milk powder another thirds. MD is mainly due to the depletion of chromium, copper, iron and nickel.

Water consumption: As can be seen in Fig. 3q, moulded chocolates consume most water $(11,372$ $\mathrm{l} / \mathrm{kg}$ ), followed by chocolates in bag $(10,484 \mathrm{l} / \mathrm{kg})$ and the countlines $(7633 \mathrm{l} / \mathrm{kg})$. However, the majority of that is green water which is entirely due to the raw materials. For the blue water consumption, chocolates in bag are the worst option, requiring $175 \mathrm{l} / \mathrm{kg}$, while moulded chocolate has the lowest consumption $(95 \mathrm{l} / \mathrm{kg}$ ); the countlines use $122 \mathrm{l} / \mathrm{kg}$. The main consumers of blue water are packaging $(44 \%-65 \%)$, the raw materials $(24 \%-43 \%)$ and manufacturing $(6 \%-11 \%)$.

Water footprint (WF): The results in Fig. 3r show that chocolates in bag have the highest WF (63 $\mathrm{l} / \mathrm{kg})$, followed by chocolate countlines $(43 \mathrm{l} / \mathrm{kg})$ and moulded chocolate $(31 \mathrm{l} / \mathrm{kg})$. As the WF considers only blue water, packaging is the main hotspot $(55 \%-73 \%)$, followed by the raw materials production (16\%-30\%) and manufacturing (7\%-13\%). 
$\square \mathrm{RM} \square \mathrm{MA} \backsim \mathrm{PA} \square \mathrm{DC} \square \mathrm{RE} \backsim \mathrm{CO} \square \mathrm{TR} \backsim \mathrm{EO}$

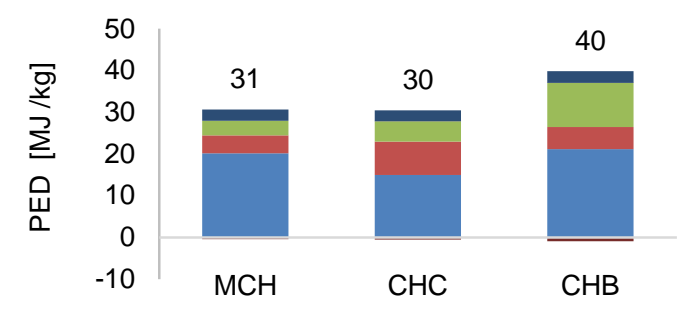

a) Primary energy demand

$\square \mathrm{RM} \backsim \mathrm{MA} \backsim \mathrm{PA} \backsim \mathrm{DC} \backsim \mathrm{RE} \backsim \mathrm{CO} \backsim \mathrm{TR} \backsim \mathrm{EOL}$

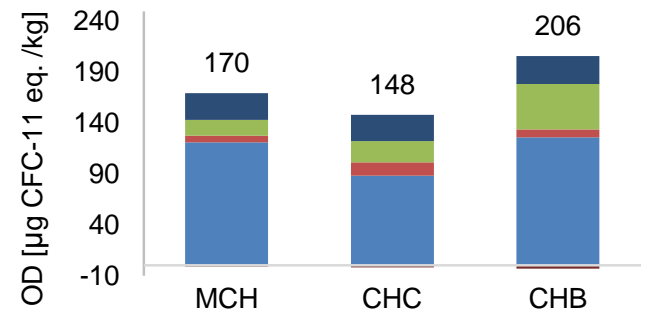

d) Ozone layer depletion

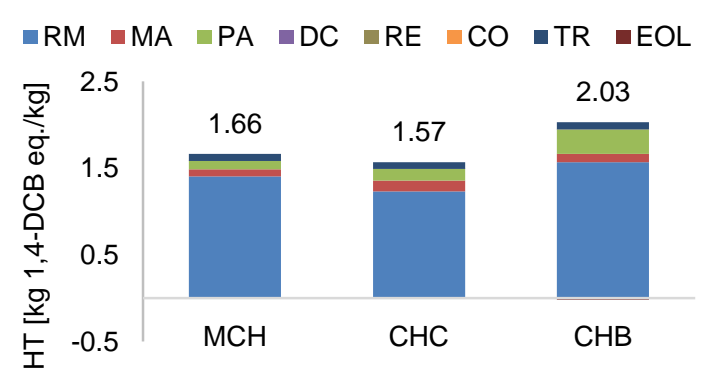

g) Human toxicity $\square \mathrm{RM} \backsim \mathrm{MA} \backsim \mathrm{PA} \backsim \mathrm{DC} \backsim \mathrm{RE} \backsim \mathrm{CO} \backsim \mathrm{TR} \backsim \mathrm{EOL}$

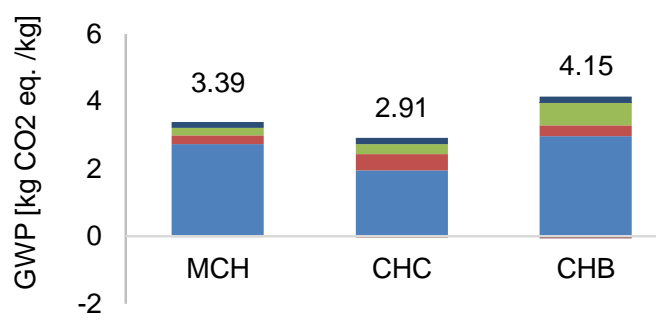

b) Global warming potential

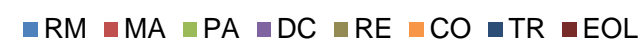

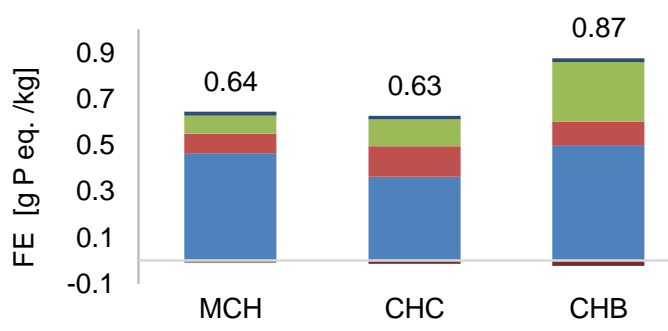

e) Freshwater eutrophication $\square \mathrm{RM} \backsim \mathrm{MA} \backsim \mathrm{PA} \backsim \mathrm{DC} \backsim \mathrm{RE} \backsim \mathrm{CO} \backsim \mathrm{TR} \backsim \mathrm{EOL}$

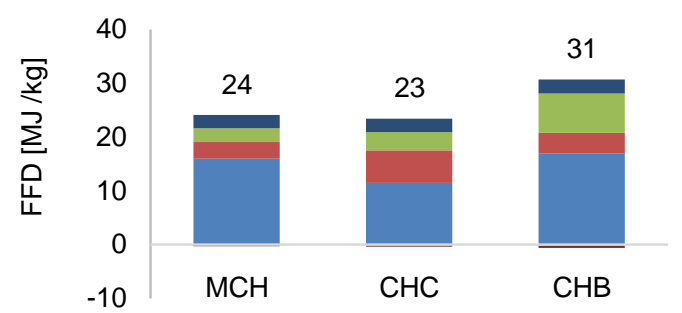

c) Fossil fuel depletion

$\because \mathrm{RM} \backsim \mathrm{MA} \backsim \mathrm{PA} \backsim \mathrm{DC} \backsim \mathrm{RE} \backsim \mathrm{CO} \backsim \mathrm{TR} \backsim \mathrm{EOL}$

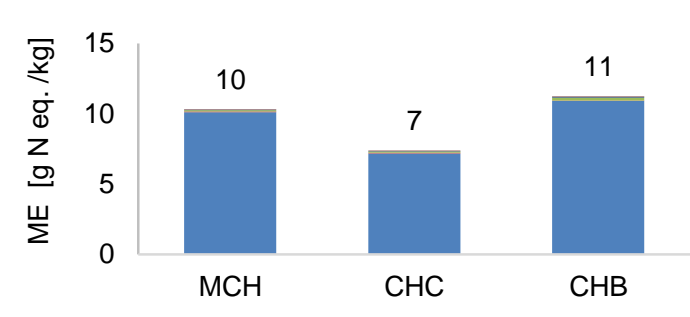

f) Marine eutrophication

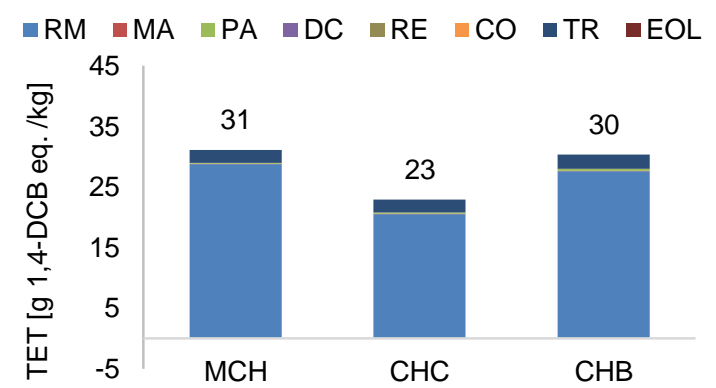

h) Terrestrial ecotoxicity $\square \mathrm{RM} \square \mathrm{MA} \square \mathrm{PA} \square \mathrm{DC} \square \mathrm{RE} \backsim \mathrm{CO} \square \mathrm{TR} \square \mathrm{EOL}$

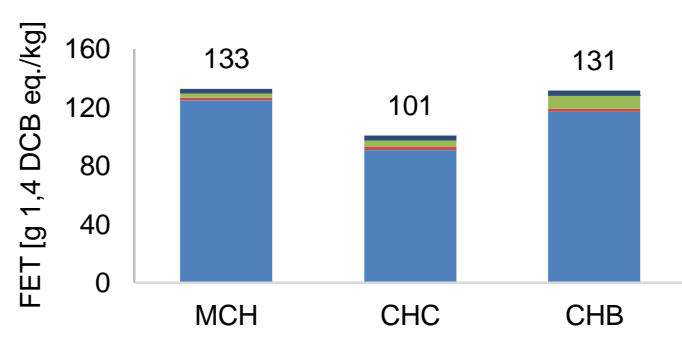

i) Freshwater ecotoxicity 
$\because \mathrm{RM} \backsim \mathrm{MA}\|\mathrm{PA}\| \mathrm{DC} \approx \mathrm{RE} \backsim \mathrm{CO}\|\mathrm{TR}\| \mathrm{EOL}$

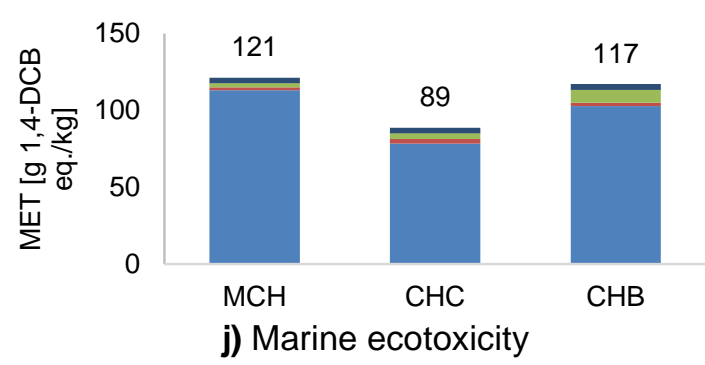

$\square \mathrm{RM} \backsim \mathrm{MA} \square \mathrm{PA} \square \mathrm{DC} \square \mathrm{RE} \square \mathrm{CO} \square \mathrm{TR} \square \mathrm{EOL}$

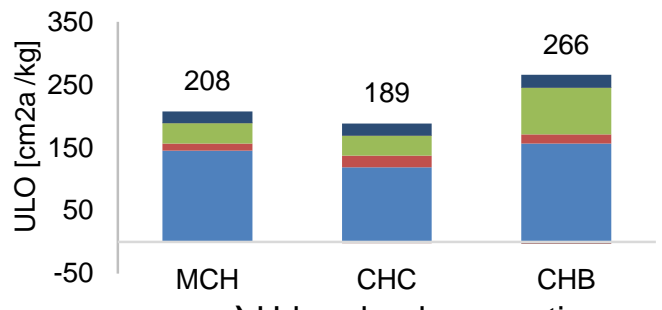

m) Urban land occupation

$\because \mathrm{RM} \backsim \mathrm{MA} \square \mathrm{PA} \backsim \mathrm{DC} \square \mathrm{RE} \backsim \mathrm{CO} \backsim \mathrm{TR} \backsim \mathrm{EO}$

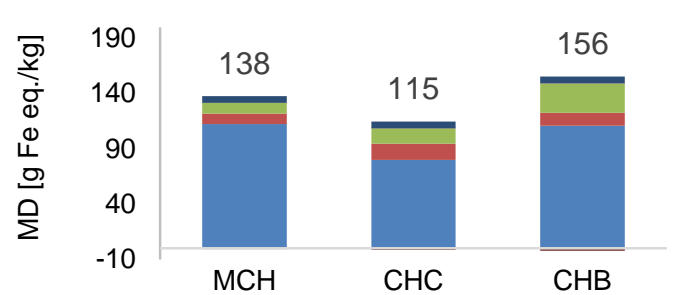

p) Mineral depletion $\square \mathrm{RM} \square \mathrm{MA} \square \mathrm{PA} \square \mathrm{DC} \square \mathrm{RE} \backsim \mathrm{CO} \square \mathrm{TR} \square \mathrm{EOL}$

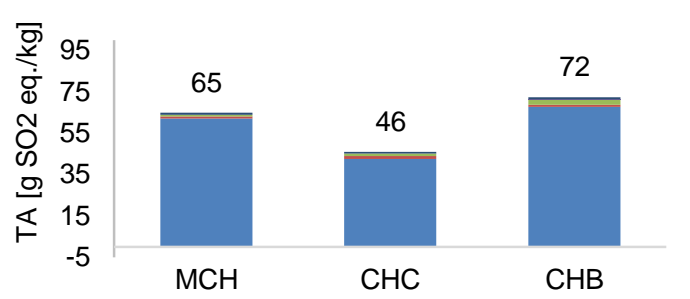

k) Terrestrial acidification

$\square \mathrm{RM} \square \mathrm{MA} \square \mathrm{PA} \square \mathrm{DC} \square \mathrm{RE} \square \mathrm{CO} \square \mathrm{TR} \square \mathrm{EOL}$

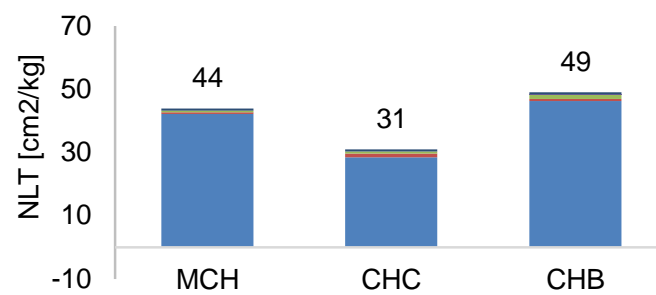

n) Natural land transformation

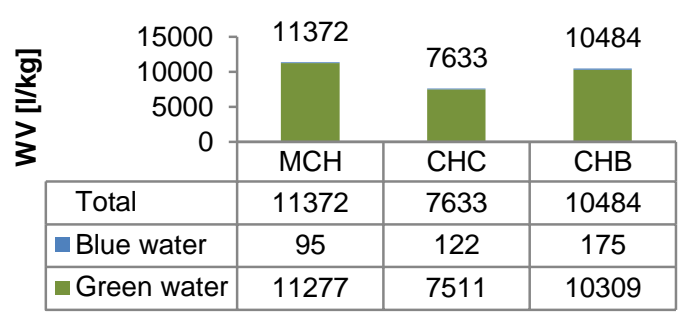

q) Water consumption
$=\mathrm{RM}=\mathrm{MA} \backsim \mathrm{PA}=\mathrm{DC}-\mathrm{RE}=\mathrm{CO}-\mathrm{TR}-\mathrm{EOL}$

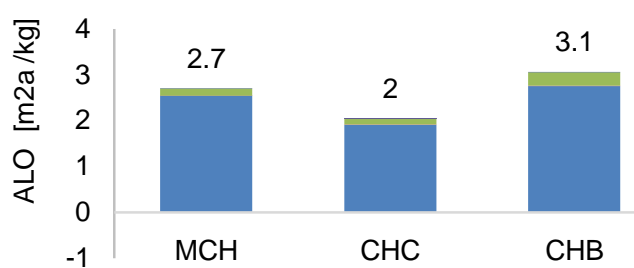

I) Agricultural land occupation $\square \mathrm{RM} \square \mathrm{MA} \square \mathrm{PA} \square \mathrm{DC} \square \mathrm{RE} \square \mathrm{CO} \square \mathrm{TR} \square \mathrm{EOL}$

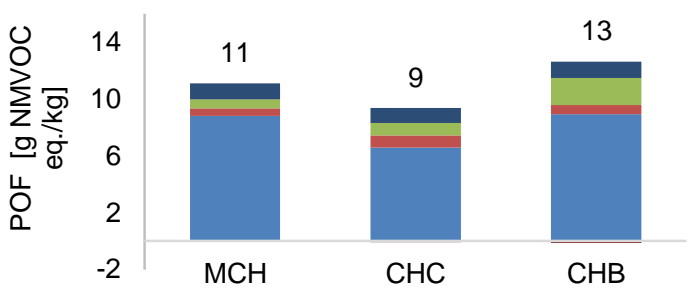

o) Photochemical oxidant formation $\square \mathrm{RM} \square \mathrm{MA} \square \mathrm{PA} \square \mathrm{DC} \square \mathrm{RE} \square \mathrm{CO} \square \mathrm{TR} \square \mathrm{EOL}$

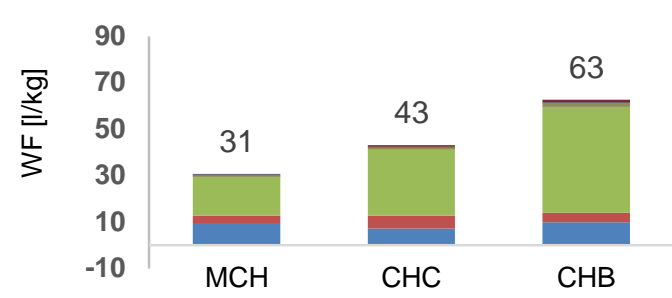

r) Water footprint

Fig. 3. Environmental impacts of different chocolate products showing contribution of different life cycle stages [MCH: Moulded chocolate; $\mathrm{CHC}$ : chocolate countlines; $\mathrm{CHB}$ : chocolate in bag. RM: Raw materials; MA: Manufacturing (of chocolates); PA: Packaging: DC: Distribution centres and retailers; RE: Recycling; CO: Co-products; TR: Transport; EOL: end of life. DCB: dichlorobenzene]. 


\subsection{Comparison of results with literature}

As mentioned in the introduction, a limited number of LCA studies of chocolates are available in the literature, with most focusing on dark chocolate. Hence, direct comparison of the results with those studies is not possible. The only study that is relevant to the current work is that by Busser \& Jungbluth (2009) which considered the environmental impacts of milk chocolate bars (moulded chocolate) manufactured and consumed in Europe. Although the authors estimated ten environmental impacts (albeit not using the ReCiPe method), only the value for GWP was available in the public domain. This shows a remarkable agreement with the estimate obtained here, being only $6 \%$ higher: 3.6 vs $3.39 \mathrm{~kg} \mathrm{CO}_{2}$ eq. $/ \mathrm{kg}$. This difference is mainly due to different transport distances and the energy mix. There is also a good agreement between the PED estimates in this study (31-40 MJ/kg) and across all other studies (33-40 MJ/kg) as energy consumption is not so much affected by the type of chocolate. All the studies also found that the cultivation of cocoa beans was the main environmental hotspot, followed by chocolate manufacturing and packaging. This is in agreement with the findings of the current study.

\subsection{Sensitivity analysis}

Given the significant contribution of the raw materials to the impacts, the sensitivity analysis explores the effect on the results of the following aspects:

- the amount of raw milk used to produce milk powder;

- land-use change (LUC) related to cocoa production;

- losses of raw materials during chocolate production;

- sources of data for cocoa beans cultivation; and

- mass allocation instead of the economic.

Furthermore, as chocolate production and packaging were also significant contributors to some impacts, the sensitivity analysis also considers different energy consumption in the chocolate production process and losses of packaging during their manufacture. The results are discussed in turn in the next sections; for further detail, see Tables S-3.1-S-3.3.

\subsubsection{Amount of raw milk used to produce milk powder}

The amount of raw milk required to produce milk powder varies among different studies. In the base case analysis, the data from Scottish Government (2011) were used which specified that $7.69 \mathrm{~kg}$ raw milk was required to produce $1 \mathrm{~kg}$ of milk powder. Finnegan et al. (2017) reported two different values: 5.12 and $9.22 \mathrm{~kg}$ of raw milk/kg milk powder. These two values are considered as part of the sensitivity analysis and the results are shown in Fig. 4.

Reducing the amount of milk by $33 \%$ (from 7.69 to $5.12 \mathrm{~kg}$ ) reduces the impacts by $5 \%-30 \%$ relative to the base case (Fig. 4a). The geatest reductions are found for marine eutrophication, terrestrial acidification, global warming potential and natural land transformation. However, if the amount of milk is increased by $44 \%$ (to $9.22 \mathrm{~kg}$ ), the impacts increase from 3\%-19\% (Fig. 4b). Therefore, most impacts are sensitive to this variable.

\subsubsection{LUC related to cocoa production}

As cocoa production is increasing due to a growing demand for chocolate, it is important to consider the effect of LUC on climate change. Using DEFRA (2009) data for LUC for cocoa cultivation, the results in Fig. 5 indicate that there is a 3-4 fold increase in GWP in comparison to the base case in which no LUC was considered. More than $70 \%$ of the total impact is now due to cocoa butter and liquor as opposed to the base case where milk powder was the most significant contributor. Thus, the effect of LUC is very significant and should be considered on a case-to-case basis, depending on where the cocoa is sourced from and if the LUC was involved. However, the data for cocoa LUC should be treated with caution due to a high uncertainty, as acknowledged by DEFRA (2009). 


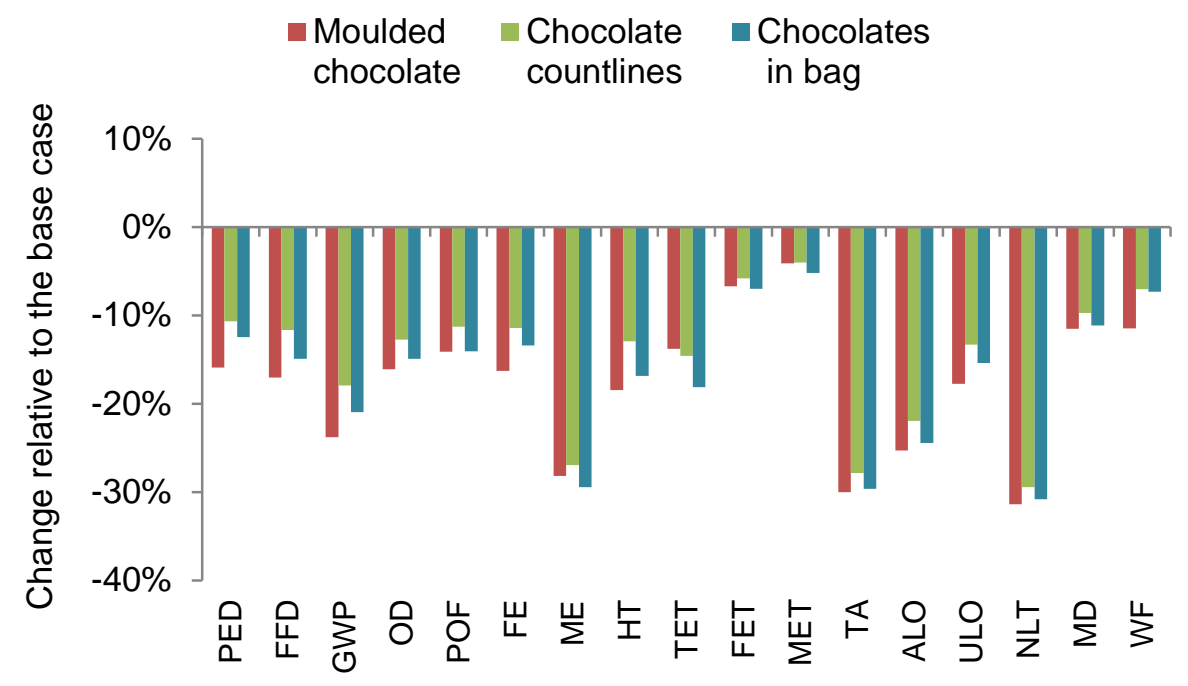

a) Lower amount of raw milk compared to the base case (5.12 vs $7.69 \mathrm{l} / \mathrm{kg}$ milk powder).

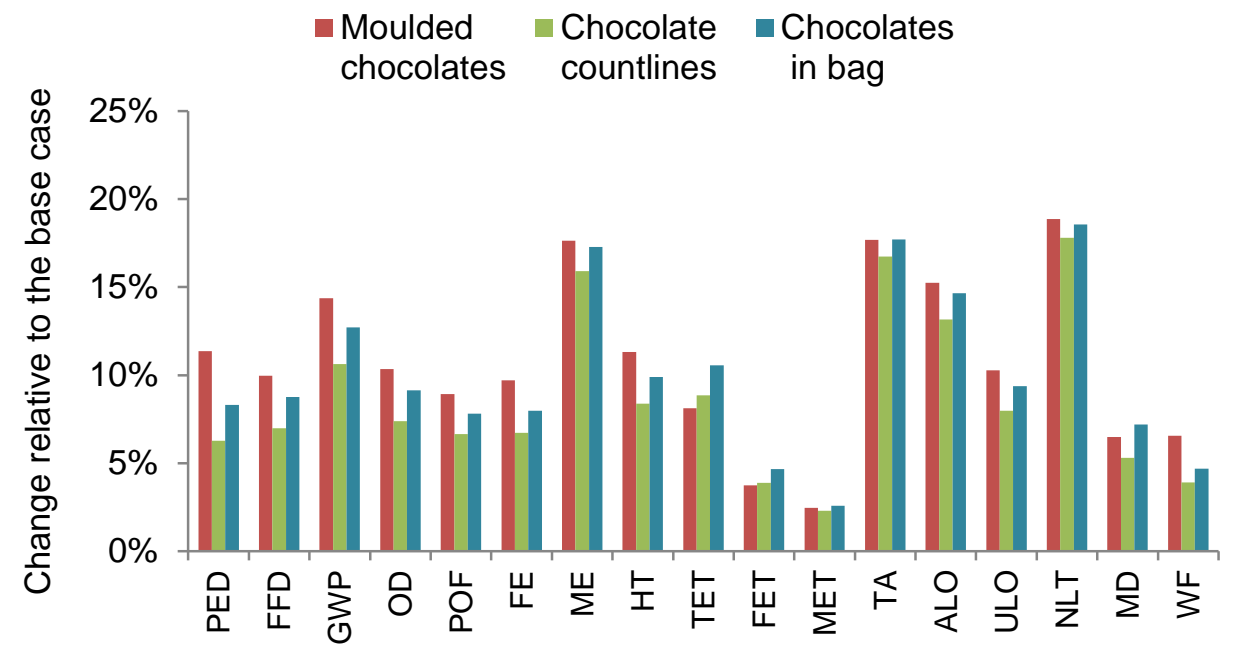

b) Higher amount of raw milk compared to the base case (9.22 vs $7.69 \mathrm{l} / \mathrm{kg}$ milk powder.

Fig. 4. The effect on the impacts of the amount of raw milk used for producing milk powder [For the impacts nomenclature, see Fig. 3].

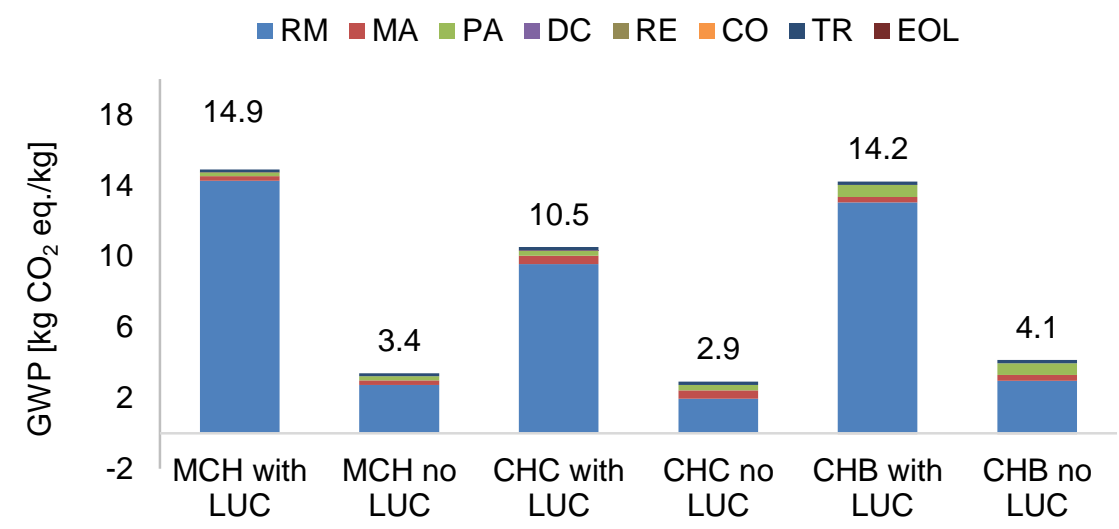

Fig. 5. Global warming potential (GWP) of three types of chocolate considering the land-use change (LUC) [For the acronyms, see Fig. 3]. 


\subsubsection{Losses of raw materials during chocolate production}

To evaluate the effect of raw material losses in the manufacturing process, the loss of $2 \%$ assumed in the base case was increased first to $5 \%$ and then to $10 \%$. The latter is unlikely as it would represent significant financial losses but is considered nevertheless to find out how sensitive the results are to this parameter. The results suggest that increasing the losses to $5 \%$ increases the impacts by $2 \%-5 \%$ for the moulded chocolate and the countlines and by 3\%-11\% for chocolates in bag (see Table S-3.1). The impacts increase further with $10 \%$ losses, from $5 \%$ for fossil fuel depletion for the countlines to $23 \%$ for terrestrial ecotoxicity for chocolates in bag. Therefore, a small to moderate sensitivity can be observed for the raw material losses in the manufacturing process.

\subsubsection{Data sources for cocoa beans cultivation}

This part of the sensitivity analysis considers the effect on the impacts of using Ecoinvent V3.3 data for the cultivation of cocoa beans, instead of the data from EC (2015a) used in the base case. The results in Fig. 6 and Table S-3.2 show a significant change in the impacts, especially for energy consumption, ozone depletion, photochemical oxidant formation, eutrophication and human toxicity. The effect is particularly pronounced for the moulded chocolates, where some impacts increase by more than $100 \%$. On the other hand, marine ecotoxicity is lower by $14 \%$ for all three chocolate types. Thus, as often happens in LCA, different sources of data for key impact contributors can change the results significantly and should be considered carefully.

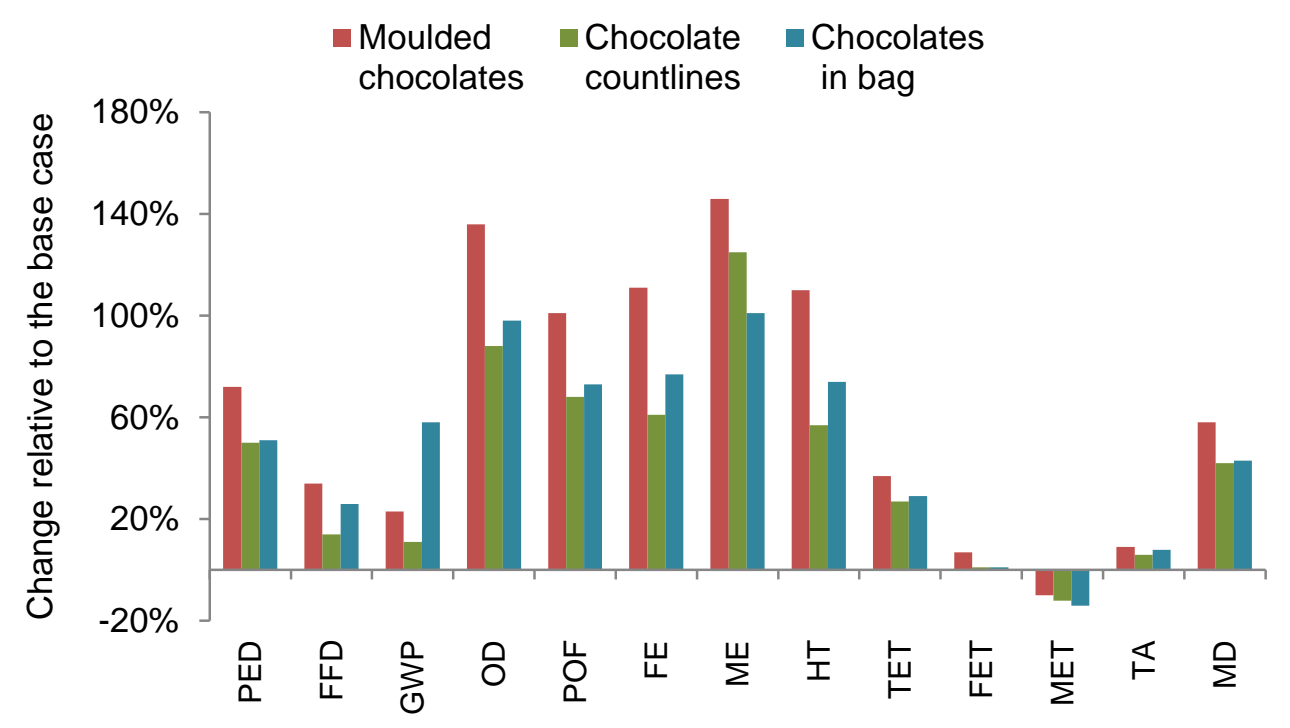

Fig. 6. The effect on the impacts of using a different data source for cocoa beans cultivation [Data in the base case are from EC (2015a) and data used in the sensitivity analysis are from Ecoinvent V3.3 (Ecoinvent, 2016). For the impacts nomenclature, see Fig. 3].

\subsubsection{Economic vs mass allocation}

In the base case, economic allocation was used for the co-products of cocoa, milk powder and wheat flour. As shown in Fig. 7, using mass allocation instead changes the impact by less than $2 \%$ compared to the base case. Hence, the choice of allocation method has no significant effect on the results for the products considered. 


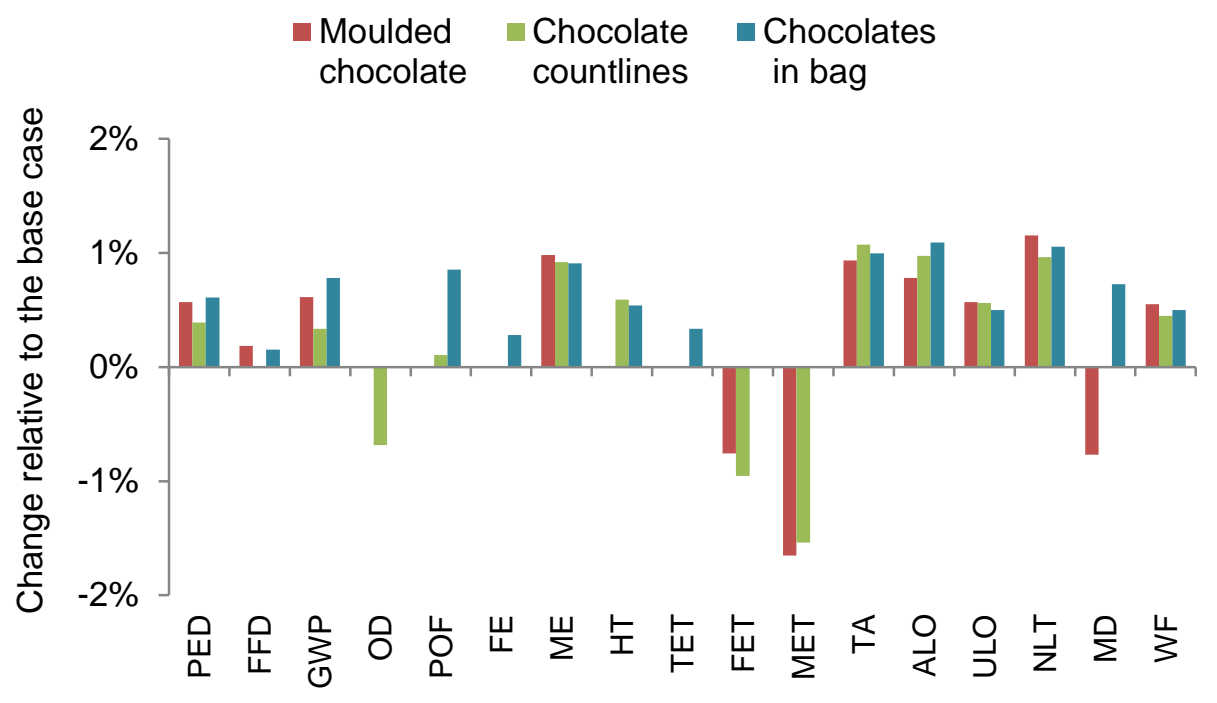

Fig. 7. The effect on the impacts of mass allocation compared to economic allocation [For the impacts nomenclature, see Fig. 3].

\subsubsection{Energy consumption for chocolate production}

Two options were considered for energy consumption in the manufacturing process: the first assumes a $50 \%$ increase in energy consumption relative to the base case and the second a $100 \%$ increase. The results in Fig. 8 show that the chocolate countlines are most affected by the variations in energy consumption while the effect on the other two products is smaller and similar to each other. For the $50 \%$ higher energy consumption (Fig. 8a), the impact categories most affected are primary energy demand (7\%-13\%), fossil fuel depletion (6\%$13 \%)$, global warming potential $(4 \%-8 \%)$ and freshwater eutrophication $(6 \%-11 \%)$. The effect on the rest of the impacts is negligible.

If the energy use is doubled on the base case (Fig. 8b), the energy-related categories increase by more than $20 \%$ in the case of chocolate countlines. Additionally, freshwater eutrophication and global warming potential rise by more than $10 \%$ for this product category. Thus, the sensitivity of impacts with respect to the energy consumption is moderate.

\subsubsection{Packaging losses}

Considering the loss of packaging in their manufacturing process in the range from $2 \%$ to $10 \%$ has no influence on the impacts categories, except for a small effect on water consumption. As can be seen in Fig. 9, the increase in blue water consumption and the related water footprint becomes notable only at a $10 \%$ loss (4.5\%-6\%). However, such a high rate of packaging loss is probably unrealistic due to the associated financial penalties. Hence, it can be concluded that the results are not sensitive to packaging losses. 


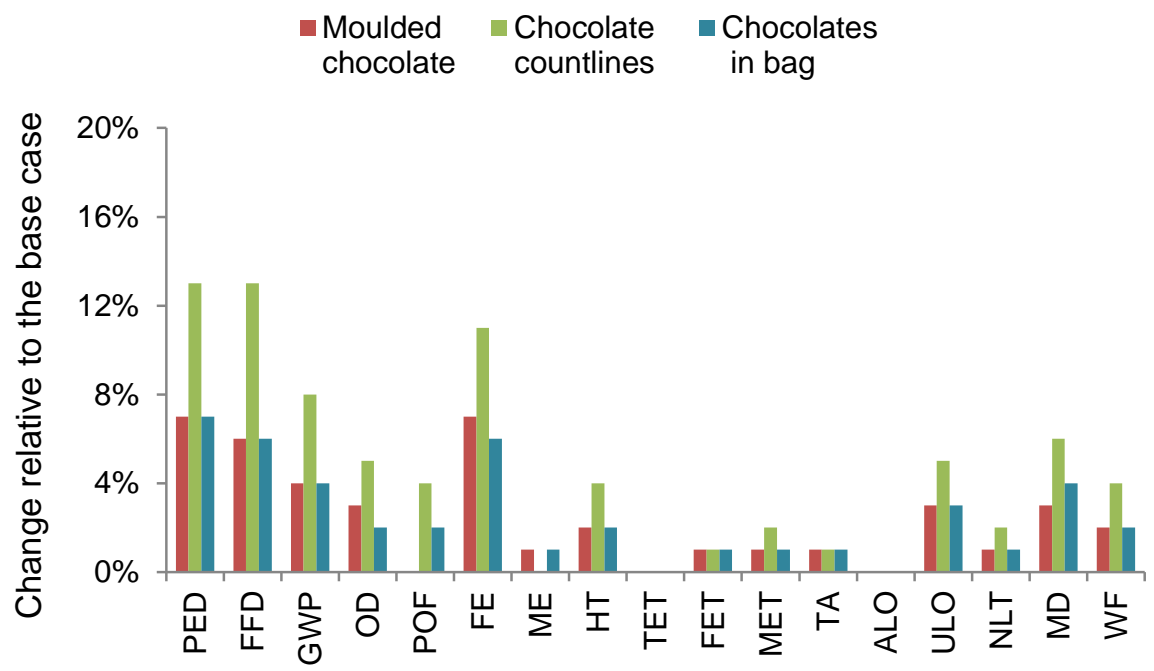

a) $50 \%$ increase

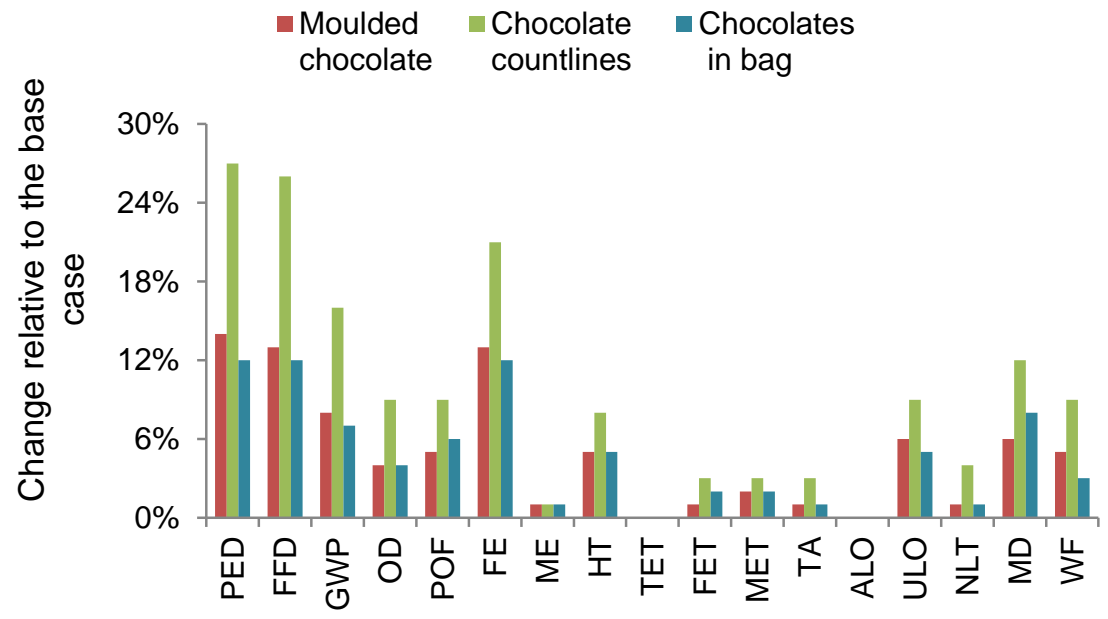

b) $100 \%$ increase

Fig. 8. The effect on the impacts of increasing energy consumption in the manufacturing processes

[For the impacts nomenclature, see Fig. 3].

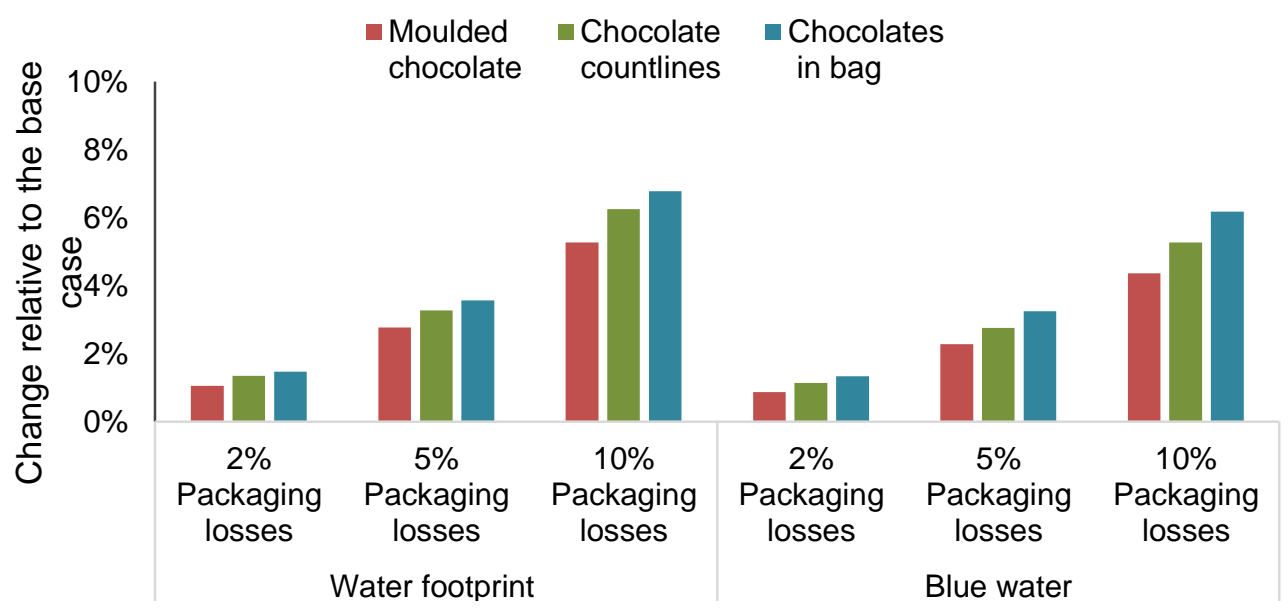

Fig. 9 The effect on the water consumption of packaging losses [No packaging losses assumed in the base case]. 


\subsection{Uncertainty analysis}

An uncertainty analysis was carried out to assess the robustness of the results against a plausible range of variations in different $\mathrm{LCI}$ parameters. For this purpose, the variations in the following parameters influencing the results were considered:

- the amount of raw milk required to produce milk powder: $5.12-9.22 \mathrm{~kg} / \mathrm{kg}$ milk powder;

- losses of raw materials in the manufacturing process: $2 \%-10 \%$ of the final product; and

- energy consumption in the manufacturing process: a 100\% increase on the base case.

Uniform distributions were assumed for all parameter values due to a lack of information on their actual distributions. Monte Carlo simulations with 10,000 iterations and $90 \%$ confidence intervals were performed to estimate the fluctuations of the impacts.

The results in Fig. 10 show that the impacts vary from $3 \%$ to $20 \%$ relative to the base case. The greatest variations of $15 \%-20 \%$ were found for primary energy demand, global warming, marine eutrophication, human toxicity, terrestrial acidification, agricultural land occupation and natural land transformation. Fluctuations of up to $10 \%$ can be observed for fossil fuel and ozone depletion, photochemical oxidant formation, freshwater eutrophication, terrestrial ecotoxicity and urban land occupation. Therefore, it can be concluded that the results are robust, given the significant variations in the parameters considered.

$$
\begin{aligned}
& \text { Moulded Chocolate } \quad \text { Chocolates } \\
& \text { chocolate countlines in bag }
\end{aligned}
$$

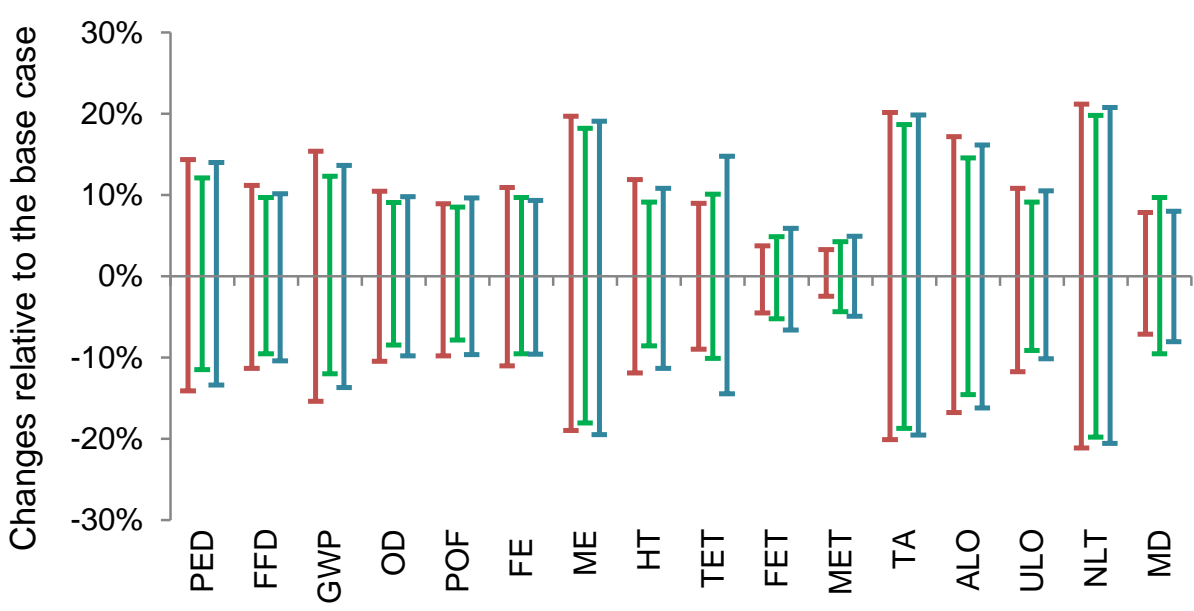

Fig. 10. The results of the uncertainty analysis showing fluctuation of the impacts with different parameters relative to the base case

[For the impacts nomenclature, see Fig. 3].

\subsection{Environmental impacts of chocolate consumption in the UK}

This section analyses the environmental impacts of annual chocolate consumption in the UK based on the results presented in the previous sections and the amount of the products considered sold annually. The data for the latter were not available and were estimated in this study based on the market share of the different product categories (Key Note, 2015) and their market prices obtained from major retailers as part of this research. As a result, the annual sales volume of different chocolate product categories were estimated as follows:

- moulded chocolates: 112,667 tonnes;

- chocolate countlines: 302,833 tonnes;

- chocolates in bag: 157,108 tonnes; and

- other chocolate confectionary: 63,000 tonnes. 
Thus, a total of 635,608 tonnes of various chocolate products were estimated to be consumed annually in the UK. Scaling up the impacts per $\mathrm{kg}$ of different products discussed in the previous sections to their respective annual consumption gives the total annual impacts presented in Fig. 11. In the absence of data for the category "other chocolate confectionary", a conservative approach was taken assuming that their impact in each category is the same as the highest impact of the other three products for that category.

It can be seen in Fig. 11 that, for example, the sectoral primary energy consumption amounts to $21,370 \mathrm{TJ} / \mathrm{yr}$ and the GWP to $2.1 \mathrm{Mt} \mathrm{CO}_{2}$ eq./yr. The former represents $4.7 \%$ of the overall energy consumed in the food and drink sector, based on the estimates for the total primary energy consumption in the UK food and drink sector of $126 \mathrm{TWh} / \mathrm{yr}$ (DEFRA, 2006). However, the latter only considers energy used in production processes and excludes the energy consumption in the rest of the life cycle. Thus, the estimates for energy use in the UK food and drink sector are underestimated, which means that the contribution of the chocolate sector to the total sectoral energy consumption is even lower. Therefore, energy consumption is not a significant factor for the chocolate sector.

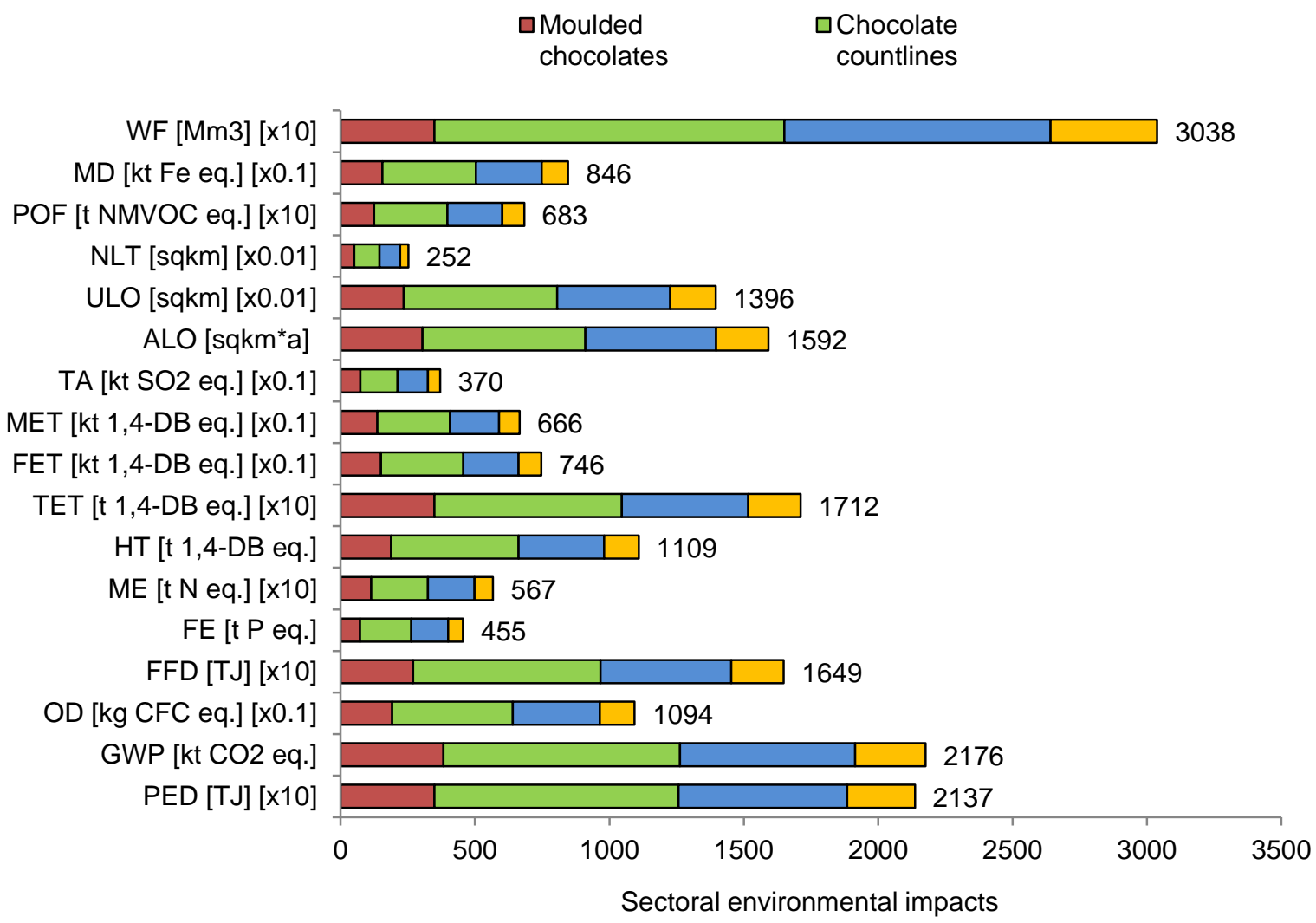

Fig. 11. Annual environmental impacts of chocolate production and consumption in the UK [Some impacts have been scaled to fit. To obtain the original values, multiply by the factor in brackets for relevant impacts. For the impacts nomenclature, see Fig. 3].

However, the contribution of greenhouse gas (GHG) emissions from the chocolate sector to the total UK emissions is more notable. Taking the consumption perspective and considering the total UK GHG emissions of around $550 \mathrm{Mt} \mathrm{CO}_{2}$ eq. per year (Druckman \& Jackson, 2009), the chocolate subsector contributes $0.38 \%$ to the total national GWP. According to the above authors, the contribution of the food sector to the total UK emissions is $15 \%$, which means that the chocolate sector is responsible for $2.4 \%$ of the total UK food-related GWP. However, it should be noted that the data in Druckman \& Jackson are from dated (from 2004) and are also by the authors' own admission underestimated due to the method used. Hence, the estimates of the contribution of the chocolate sector to the total should be 
interpreted with this in mind. The other impacts are more difficult to put into context as there are no sectoral or national data.

Fig. 11 also shows that chocolate countlines have the highest contribution to all the impact categories, which ranges from $37 \%-43 \%$ of the total. This is followed by chocolates in bag with the contributions of $28 \%-33 \%$. The contributions from moulded chocolates and other chocolate confectionary are similar to each other and make up the rest of the impacts.

\subsection{Improvement opportunities}

According to the results, the production of milk powder and cocoa derivatives, along with the manufacturing process, are the main contributors to the impacts and should therefore be targeted for improvements. These are considered below. Packaging has also been identified as a significant contributor to some of the impacts and should also be subject to improvements. However, packaging is not considered here due to a lack of data for alternative packaging that could be used instead while preserving functionality.

Since the vast majority of the milk powder impacts are associated with the raw milk production at farm, two possible improvement opportunities related to the raw milk production are considered: i) manure composting instead of leaving it on the land as in the base case; and ii) a $20 \%$ energy reduction in the milk parlour due to more efficient energy management. The results suggest that through these improvements the GWP of moulded chocolate would be reduced by $12 \%$, fossil fuel depletion by $5 \%$ and freshwater eutrophication by $4 \%$ (Table S-4). For chocolates in bag, 11\% of GWP and $5 \%$ of fossil fuel depletion would be avoided. The GWP savings for the chocolate countlines would be around $9 \%$ but the other categories would not be influenced. Thus, in accordance with the sensitivity analysis results, a lower amount of raw milk used for producing milk powder could mitigate the environmental impacts more effectively as a result of more efficient manufacturing process. A further improvement option that could be considered is to modify the cows' diet to reduce methane emissions from enteric fermentation. For example, Roibas et al. (2016) considered the effect on the emissions of the addition of linseeds to the feed and found that the GWP of milk was reduced by $10 \%$. Applying this potential reduction to the milk production in this study would reduce the overall GWP of chocolates by $5 \%-7 \%$.

Cocoa butter and liquor have significant ecotoxicity impacts. According to Ntiamoah \& Afrane (2008), these could be reduced through the following measures: i) use of organic fertilisers combined with their more efficient application; ii) a $50 \%$ reduction of conventional fertiliser use; and iii) a 50\% reduction in the amount of pesticides used. However, yield decreases should also be considered if applying these measures. Further consideration of these is beyond the scope of this paper.

Improvements in the manufacturing process considered here are related to a more efficient energy use, assuming a 15\%-25\% reduction. These improvements could be achieved through implementation of integrated energy management systems or more advanced and innovative production technologies. The results suggests that energy savings of more than $20 \%$ could lead to reductions in most impacts but these would be small, ranging from $3 \%$ for the moulded and chocolates in bag to $5 \%$ for the countlines.

\section{Conclusions}

This study assessed the life cycle environmental impacts associated with the main chocolate products produced and consumed in the UK: moulded chocolates, chocolate countlines and chocolates in bag. The results suggest that the raw materials production is the major hotspot across all impact categories. Packaging and manufacturing also influence the impacts, while transport has a significant contribution to ozone depletion, fossil fuel depletion and formation of photochemical oxidants. The impacts from the raw materials are largely due to milk 
powder production, while sugar and cocoa derivatives are significant contributors to some of the impacts. Therefore, the production of these raw materials should be targeted for environmental improvements, together with the chocolate manufacturing process and packaging. For example, composting the dairy manure, reducing energy consumption in milk parlour by $20 \%$ and supplementing cows' feed with linseeds could together reduce the GWP of chocolates by $14 \%-19 \%$.

The sensitivity analysis shows that the results for global warming potential are very sensitive to land-use change associated with cocoa production, increasing the impact of chocolate products by a three to four times if LUC is involved. The assumptions on the amount of milk used to produce milk powder also influence the results significantly, while the effect of the assumptions for energy consumption and losses of raw materials in the manufacturing process is moderate. The influence of using mass instead of economic allocation is negligible. The uncertainty analysis demonstrates that the obtained results are robust.

The impacts estimated per kilogram of each product type were scaled up to the annual consumption of chocolate in the UK to evaluate the overall environmental implications. The results suggest that around $21 \mathrm{TJ}$ of primary energy is consumed and $2.1 \mathrm{Mt} \mathrm{CO}_{2}$ eq. are emitted annually to produce and supply $635.6 \mathrm{kt}$ of chocolate products to UK consumers. The latter represents $2.4 \%$ of the GHG emissions from the whole food and drink sector in the UK. Among the product types considered, chocolate countlines have the highest contribution to the total $(37 \%-43 \%)$, followed by chocolates in bag (28\%-33\%). Moulded chocolates and the other chocolate confectionary make up the rest of the impacts, with a roughly equal share each. The results of this work can be used by policy makers and producers to target the identified hotspots for improvements and monitor future progress of the sector. The findings will also be of interest to consumers, helping them make informed choices towards sustainable consumption of chocolate products.

\section{Acknowledgement}

This research has been founded by the UK Engineering and Physical Sciences Research Council, EPSRC (Grant no. EP/F007132/1). This funding is gratefully acknowledged.

\section{Appendix A. Supplementary data}

The Supporting information includes data on the contribution of different life cycle stages to the total impacts and the results of the sensitivity and improvement opportunities analyses.

\section{References}

Afoakwa, E. O., 2016. Chocolate Science and Technology. 2nd ed. Oxford: Wiley Blackwell.

Audsley, A. et al., 2009. How long can we go? An assessment of greenhouse gas emissions from the UK food system and the scope to reduce them by 2050, Cranfield, UK: RCRNWWF-UK.

Beckett, S. T., 2009. Industrial Chocolate Manufacture and Use. 4th ed. Singapore: Blackwell.

Blonk, 2015. Agri - Footprint - LCA database. Gouda, The Netherlands: Blonk consultants.

Brush, A., Masanet, E. \& Worrel, E., 2011. Energy efficiency improvement and cost saving opportunities for the dairy processing industry, Berkeley, California: Ernest Orlando Lawrence Berkeley National Laboratory.

Busser, S. \& Jungbluth, N., 2009. LCA of chocolate packed in aluminium foil based packaging, Dusseldorf, Germany: German Aluminium Association.

Caobisco, 2015. Chocolate, Biscuits \& Confectionery of Europe. [Online] Available at: http://caobisco.eu/ [Accessed 10 March 2015].

CCaLC, 2015. CCaLC 3.3 software and database. [Online] Available at: www.ccalc.org.uk. 
Classen, M. et al., 2009. Life Cycle Inventories of Metals. Final report data V2.1, No 10, Dubendorf: Swiss Centre for life Cycle Inventories. Cranfield University, 2005. AgriLCA. [Online] Available at: http://urlm.co.uk/www.agrilca.co.uk [Accessed 15 March 2015].

DairyCo, 2015. DairyCo product prices. [Online] Available at: www.dairyco.org.uk [Accessed 12 Dec 2015].

DEFRA, 2006. Food industry sustainability strategy. Department for Environment, Food and Rural Affairs, London. [Online] Available at: www.defra.gov.uk/publications/2011/03/28/pb11649-food-industry [Accessed 1 Oct 2017].

DEFRA, 2009. Scenario building to test and inform development of a BSI method for assessing greenhouse gas emissions from food. Project FO0404, Department of Environment and Rural Affairs, London.

DeJong, P., 2013. Sustainable dairy production. Oxford: Wiley-Blackwell.

Druckman, A. \& Jackson, T., 2009. The carbon footprint of UK households 1990-2004: A socio-economically disaggregated, quasi-multi-regional input-output model. Ecological Economics, 68, pp. 2066-2077.

EAA, 2013. Environmental profile report for the European aluminium industry, Brussels: European Aluminium Association.

EC, 2015a. PEF for coffee screening report in the context of the EU product environmental footprint category rules (PEFCR) pilots, Brussels, Belgium: European Commission.

EC, 2015b. PEF for pasta screening report in the context of the EU product environmental footprint category rules (PEFCR) pilots, Brussels: European Commission.

EC, 2015c. PEF for beer report in the context of the EU product environmental footprint category rules (PEFCR), Brussels: European Commission.

EC, 2016a. Single market for green products. PEF/OEF: Default data to model distribution and storage. [Online] Available at: http;//ec/europa.eu/environment/eissd/smgp [Accessed 1 March 2016].

EC, 2016b. Plastic waste statistics. [Online] Available at: http://ec.europa.eu/eurostat/web/environment/waste/maintables [Accessed 1003 2015].

EC, 2016c. Commercial waste statistics. [Online] Available at: http://ec.europa.eu/eurostat/web/environment/waste/maintables [Accessed 1901 2016].

Ecoinvent, 2010. Ecoinvent V2.2 database, Duebendorf, Switzerland: Swiss Centre for Life Cycle Inventories.

Ecoinvent, 2016. Ecoinvent 3.3 database, Duebendorf, Switzerland: Swiss Centre for Life Cycle Inventories.

Envirochemie, 2016. Wastewater treatment in the dairy processing industry. [Online]

Available at: https://envirochemie.com/cms/upload/downloadsen/fachbeitraege/Whitepaper Wastewater treatment in the dairy processing industry .pdf [Accessed 2010 2016].

Finnegan, W., Goggins, J., Clifford, E. \& Zhan, X., 2017. Environmental impacts of milk powder and butter manufactured in the Rebublic of Ireand. Science of the Total Environment, Volume 579, pp. 159-168.

Goedkoop, M. et al., 2013. ReCiPe 2008: A life cycle impact assessment method which comprises harmonised category indicators at the midpoint and the endpoint level, Amsterdam: Dutch Ministry of Housing, Spatial Planning and Environment.

Hamburg \& Dresdner machine factories, 2016. Hamburg Dresdner Maschinenfabriken. [Online]. Available at: www.h-d-m.de/en/ [Accessed 3008 2016].

Hirshier, R., 2007. Life Cycle Inventories of Packaging and Graphical Papers. Ecoinvent Report No. 11, Dubendorf: Swiss Centre for Life Cycle Inventories.

Hoekstra, A. Y., Chapagain, A. K., Aldaya, M. M. \& Mekonnen, M. M., 2011. The water footprint assessment manual. Setting the global standard, London: Earthscan Ltd.

Hogaas, M. E., 2002. Life cycle assessment (LCA) of industrial milk production. Chalmers: Chalmers University of Technology.

ICCO, 2016. International Cocoa Organization. [Online] Available at: www.icco.gr [Accessed $15102016]$ 
ISO, 2006a. Environmental management - Life cycle assessment - Requirements and guidelines EN ISO 14044: 2006. London: BSI.

ISO, 2006b. Environmental management - Life cycle assessment - Principles and Framework, EN ISO 14040: 2006. London: BSI.

Key Note, 2015. Confectionary Market Report 2015, Richmond Upon Thames: Key Note.

Manley, D., 2000. Technology of biscuits, crackers and cookies. 3rd ed. Cambridge, UK: Woodhead Publishing Limited.

Manley, D., 2001. Biscuit, cracker and cookie recipes for the food industry. 3rd ed. Cambridge, UK: Woodhead Publishing Limited.

Mintel, 2015. Chocolate Confectionary UK, s.I.: Mintel.

Neira Perez, D., 2016. Energy sustainability of Ecuadorian cocoa export and its contribution to climate change. A case study through life cycle assessment. Journal of Cleaner Production. 112, pp. 2560-2568.

Ntiamoah, A. \& Afrane, G., 2008. Environmental impacts of cocoa production and processing in Ghana: life cycle assessment approach. Journal of cleaner production, Volume 16, p. 1735-1740.

Pfister, S., Koehler, A. \& Hellweg, S., 2009. Assessing the environmental impacts of freshwater consumption in LCA. Environmental Science \& Technology, Volume 43, p. 4098-4104.

Pretty, J., Ball, A., Lang, T. \& Morison, J., 2005. Farm costs and food miles: An assessment of the full cost of the UK weekly food basket. Food Policy, Volume 30, p. 1-16.

Ramirez, C. A., Patel, M. \& Blok, K., 2006. From fluid milk to milk powder: Energy use and energy efficiency in the European dairy industry. Energy, Volume 31, p. $1984-2004$.

Recanati, F., Marveggio, D. \& Dotelli, G., 2018. From beans to bar: A life cycle assessment towards sustainable chocolate supply chain. Science of The Total Environment, Volume 613-614, p. 1013-1023.

Roibas, L., Martinez, I., Goris, A., Barreiro, R., \& Hospido, A., 2016. An analysis on how switching to a more balanced and naturally improved milk would affect consumer health and the environment. Science of the Total Environment, 566-567, pp. 685-697.

Scottish Government, 2011. Scottish dairy supply chain greenhouse gas emissions, Edinburgh: Scottish Goverment.

Searates, 2015. Searates route explorer Model SN26T597GB. [Online] Available at: www.searates.com [Accessed 20 November 2015].

Statista, 2015. Retail sales of chocolate worldwide. [Online] Available at: https://www.statista.com/statistics/569521/chocolate-retail-sales-worldwide/ [Accessed 5 March 2016].

Thinkstep AG, 2016. Gabi V6.115 Version software and database. [Online] Available at: www.thinkstep.com.

UBA, 2016. PROBAS database, Berlin: German Environmental Agency.

Vesce, E. et al., 2016. Life cycle assessment as a tool to integrate environmental indicators in food products: a chocolate LCA case study. International Journal of Environment and Health, 8(1), pp. 21-37.

Westergaard, V., 2010. Milk powder technology. 5th ed. Copenhagen: GEA.

Water Footprint Network, 2016 [Online] Available at: http://waterfootprint.org [Accessed 10 04 2016]. 
Antonios Konstantas, Harish K. Jeswani, Laurence Stamford and Adisa Azapagic

\section{Supplementary information}

\section{List of contents}

Table S-1

Table S-2

Tables S-3.1-3.3

Contribution of different life cycle stages to the total impacts Contribution to the impacts of most relevant life cycle stages: raw materials, manufacturing and packaging

Table S-4 Sensitivity analysis

Improvement opportunities: manure composting and energy reduction in the milk parlour 
Table S-1 Contribution of different life cycle stages to the total impacts

\begin{tabular}{|c|c|c|c|c|c|c|c|c|}
\hline \multirow[b]{2}{*}{ Impact categories } & \multicolumn{3}{|c|}{ Life cycle stages } & \multirow{2}{*}{\multicolumn{2}{|c|}{$\begin{array}{l}\text { Distribution } \\
\text { centre }\end{array}$}} & \multirow[b]{2}{*}{ Consumption } & \multirow[b]{2}{*}{$\begin{array}{l}\text { End of } \\
\text { life }\end{array}$} & \multirow[b]{2}{*}{ Transport } \\
\hline & Chocolate types & $\begin{array}{c}\text { Raw } \\
\text { materials }\end{array}$ & Manufacturing & & & & & \\
\hline \multirow[t]{3}{*}{ Primary energy demand (PED) } & Moulded chocolates & $66 \%$ & $14 \%$ & $11 \%$ & & & & $9 \%$ \\
\hline & Countlines & $49 \%$ & $26 \%$ & $16 \%$ & & & & $9 \%$ \\
\hline & Chocolates in bag & $53 \%$ & $13 \%$ & $26 \%$ & & & & $7 \%$ \\
\hline \multirow[t]{3}{*}{ Fossil fuel depletion (FFD) } & Moulded chocolates & $66 \%$ & $13 \%$ & $11 \%$ & & & & $10 \%$ \\
\hline & Countlines & $49 \%$ & $25 \%$ & $15 \%$ & & & & $11 \%$ \\
\hline & Chocolates in bag & $55 \%$ & $12 \%$ & $24 \%$ & & & & $8 \%$ \\
\hline \multirow[t]{3}{*}{ Global warming potential (GWP) } & Moulded chocolates & $81 \%$ & $8 \%$ & $6 \%$ & & & & \\
\hline & Countlines & $67 \%$ & $16 \%$ & $11 \%$ & & & & \\
\hline & Chocolates in bag & $72 \%$ & $7 \%$ & $16 \%$ & & & & \\
\hline \multirow[t]{3}{*}{ Ozone depletion (OD) } & Moulded chocolates & $71 \%$ & & $9 \%$ & & & & $15 \%$ \\
\hline & Countlines & $60 \%$ & $9 \%$ & $14 \%$ & & & & $17 \%$ \\
\hline & Chocolates in bag & $61 \%$ & & $22 \%$ & & & & $13 \%$ \\
\hline \multirow{3}{*}{$\begin{array}{l}\text { Photochemical oxidant } \\
\text { formation (POF) }\end{array}$} & Moulded chocolates & $79 \%$ & & $6 \%$ & & & & $10 \%$ \\
\hline & Countlines & $70 \%$ & $9 \%$ & $9 \%$ & & & & $11 \%$ \\
\hline & Chocolates in bag & $70 \%$ & & $15 \%$ & & & & $9 \%$ \\
\hline \multirow{3}{*}{ Freshwater eutrophication (FE) } & Moulded chocolates & $72 \%$ & $13 \%$ & $12 \%$ & & & & \\
\hline & Countlines & $58 \%$ & $21 \%$ & $19 \%$ & & & & \\
\hline & Chocolates in bag & $57 \%$ & $12 \%$ & $29 \%$ & & & & \\
\hline \multirow[t]{3}{*}{ Marine eutrophication (ME) } & Moulded chocolates & $98 \%$ & & & & & & \\
\hline & Countlines & $97 \%$ & & & & & & \\
\hline & Chocolates in bag & $97 \%$ & & & & & & \\
\hline \multirow[t]{3}{*}{ Human toxicity $(\mathrm{HT})$} & Moulded chocolates & $85 \%$ & & $6 \%$ & & & & \\
\hline & Countlines & $78 \%$ & $8 \%$ & $9 \%$ & & & & \\
\hline & Chocolates in bag & $77 \%$ & & $14 \%$ & & & & \\
\hline \multirow[t]{3}{*}{ Terrestrial ecotoxicity (TET) } & Moulded chocolates & $92 \%$ & & & & & & $7 \%$ \\
\hline & Countlines & $90 \%$ & & & & & & $9 \%$ \\
\hline & Chocolates in bag & $91 \%$ & & & & & & $7 \%$ \\
\hline
\end{tabular}




\section{Table S-1 Continued}

\begin{tabular}{|c|c|c|c|c|c|c|c|c|}
\hline \multirow[b]{2}{*}{ Impact categories } & \multicolumn{3}{|c|}{ Life cycle stages } & \multirow{2}{*}{\multicolumn{2}{|c|}{ Distribution }} & \multirow{2}{*}{\multicolumn{2}{|c|}{$\begin{array}{l}\text { End-of- } \\
\text { life }\end{array}$}} & \multirow[b]{2}{*}{ Transport } \\
\hline & Chocolate types & $\begin{array}{c}\text { Raw } \\
\text { materials }\end{array}$ & Manufacturing & & & & & \\
\hline \multirow[t]{3}{*}{ Freshwater ecotoxicity (FET) } & Moulded chocolates & $94 \%$ & & & & & & \\
\hline & Countlines & $90 \%$ & & & & & & \\
\hline & Chocolates in bag & $90 \%$ & & & & & & \\
\hline \multirow[t]{3}{*}{ Marine ecotoxicity (MET) } & Moulded chocolates & $93 \%$ & & & & & & \\
\hline & Countlines & $88 \%$ & & & & & & \\
\hline & Chocolates in bag & $87 \%$ & & & & & & \\
\hline \multirow[t]{3}{*}{ Terrestrial acidification (TA) } & Moulded chocolates & $96 \%$ & & & & & & \\
\hline & Countlines & $92 \%$ & & & & & & \\
\hline & Chocolates in bag & $93 \%$ & & & & & & \\
\hline \multirow{3}{*}{ 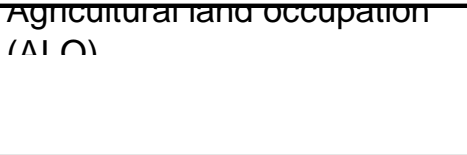 } & Moulded chocolates & $94 \%$ & & $5 \%$ & & & & \\
\hline & Countlines & $93 \%$ & & $6 \%$ & & & & \\
\hline & Chocolates in bag & $90 \%$ & & $9 \%$ & & & & \\
\hline \multirow[t]{3}{*}{ Urban land occupation (ULO) } & Moulded chocolates & $70 \%$ & $5 \%$ & $15 \%$ & & & & $9 \%$ \\
\hline & Countlines & $63 \%$ & $9 \%$ & $17 \%$ & & & & $10 \%$ \\
\hline & Chocolates in bag & $59 \%$ & & $28 \%$ & & & & $8 \%$ \\
\hline \multirow{3}{*}{ 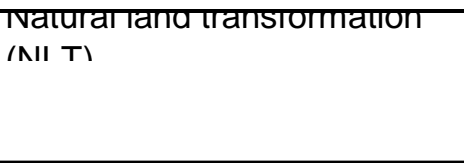 } & Moulded chocolates & $96 \%$ & & & & & & \\
\hline & Countlines & $92 \%$ & & & & & & \\
\hline & Chocolates in bag & $94 \%$ & & & & & & \\
\hline \multirow[t]{3}{*}{ Mineral depletion (MD) } & Moulded chocolates & $82 \%$ & $7 \%$ & $7 \%$ & & & & \\
\hline & Countlines & $70 \%$ & $13 \%$ & $12 \%$ & & & & \\
\hline & Chocolates in bag & $71 \%$ & $7 \%$ & $17 \%$ & & & & \\
\hline \multirow[t]{3}{*}{ Water footprint } & Moulded chocolates & $30 \%$ & $12 \%$ & $55 \%$ & & & & \\
\hline & Countlines & $17 \%$ & $13 \%$ & $66 \%$ & & & & \\
\hline & Chocolates in bag & $16 \%$ & $7 \%$ & $73 \%$ & & & & \\
\hline
\end{tabular}


Table S-2 Contribution to the impacts of most relevant life cycle stages: raw materials, manufacturing and packaging

\begin{tabular}{|c|c|c|c|c|c|c|c|c|c|c|}
\hline Impact categories & Chocolate types & $\begin{array}{r}\text { Milk } \\
\text { powder }\end{array}$ & Sugar & Flour & $\begin{array}{l}\text { Cocoa } \\
\text { butter }\end{array}$ & $\begin{array}{r}\text { Cocoa } \\
\text { mass }\end{array}$ & Palm oil & $\begin{array}{r}\text { Manufacturing } \\
\text { processes }\end{array}$ & $\begin{array}{r}\text { Primary } \\
\text { packaging }\end{array}$ & $\begin{array}{l}\text { Secondary } \\
\text { packaging }\end{array}$ \\
\hline \multirow[t]{3}{*}{ Primary energy demand (PED) } & Moulded chocolates & $47 \%$ & $7 \%$ & & $6 \%$ & & & $14 \%$ & $7 \%$ & \\
\hline & Countlines & $31 \%$ & $6 \%$ & & & & & $26 \%$ & $13 \%$ & \\
\hline & Chocolates in bag & $39 \%$ & & & & & & $13 \%$ & $21 \%$ & \\
\hline \multirow[t]{3}{*}{ Fossil fuel depletion (FFD) } & Moulded chocolates & $48 \%$ & $6 \%$ & & $6 \%$ & & & $13 \%$ & $6 \%$ & \\
\hline & Countlines & $33 \%$ & & & & & & $26 \%$ & $11 \%$ & \\
\hline & Chocolates in bag & $42 \%$ & & & & & & $12 \%$ & $18 \%$ & \\
\hline \multirow[t]{3}{*}{ Global warming potential (GWP) } & Moulded chocolates & $70 \%$ & & & & & & $8 \%$ & $6 \%$ & \\
\hline & Countlines & $54 \%$ & & & & & & $16 \%$ & $8 \%$ & \\
\hline & Chocolates in bag & $63 \%$ & & & & & & $8 \%$ & $13 \%$ & \\
\hline \multirow[t]{3}{*}{ Ozone depletion (OD) } & Moulded chocolates & $46 \%$ & $9 \%$ & & $9 \%$ & $6 \%$ & & & & \\
\hline & Countlines & $35 \%$ & $9 \%$ & & $9 \%$ & $7 \%$ & & $9 \%$ & $10 \%$ & \\
\hline & Chocolates in bag & $42 \%$ & $7 \%$ & & $7 \%$ & 6 & & & $15 \%$ & \\
\hline \multirow[t]{3}{*}{$\begin{array}{l}\text { Photochemical oxidant formation } \\
\text { (POF) }\end{array}$} & Moulded chocolates & $42 \%$ & $22 \%$ & & $6 \%$ & & & & & \\
\hline & Countlines & $33 \%$ & $22 \%$ & & & & & $9 \%$ & $7 \%$ & \\
\hline & Chocolates in bag & $41 \%$ & $19 \%$ & & & & & $6 \%$ & $11 \%$ & \\
\hline \multirow[t]{3}{*}{ Freshwater eutrophication (FE) } & Moulded chocolates & $48 \%$ & $7 \%$ & & $9 \%$ & $7 \%$ & & $13 \%$ & $9 \%$ & \\
\hline & Countlines & $32 \%$ & $6 \%$ & & $7 \%$ & $6 \%$ & & $21 \%$ & $16 \%$ & \\
\hline & Chocolates in bag & $39 \%$ & $5 \%$ & & $7 \%$ & $4 \%$ & & $12 \%$ & $25 \%$ & \\
\hline \multirow[t]{3}{*}{ Marine eutrophication (ME) } & Moulded chocolates & $85 \%$ & $10 \%$ & & & & & & & \\
\hline & Countlines & $79 \%$ & $12 \%$ & & & & & & & \\
\hline & Chocolates in bag & $86 \%$ & $9 \%$ & & & & & & & \\
\hline \multirow[t]{3}{*}{ Human toxicity $(\mathrm{HT})$} & Moulded chocolates & $54 \%$ & $13 \%$ & & $7 \%$ & & & & & \\
\hline & Countlines & $38 \%$ & $12 \%$ & $14 \%$ & & & & $8 \%$ & $7 \%$ & \\
\hline & Chocolates in bag & $49 \%$ & $10 \%$ & & $6 \%$ & & & $6 \%$ & $11 \%$ & \\
\hline \multirow[t]{3}{*}{ Terrestrial ecotoxicity (TET) } & Moulded chocolates & $39 \%$ & $20 \%$ & & $7 \%$ & & $21 \%$ & & & \\
\hline & Countlines & $35 \%$ & $24 \%$ & & $6 \%$ & & $19 \%$ & & & \\
\hline & Chocolates in bag & $44 \%$ & $20 \%$ & & $7 \%$ & & $16 \%$ & & & \\
\hline
\end{tabular}




\begin{tabular}{|c|c|c|c|c|c|c|c|c|c|c|}
\hline Impact categories & Chocolate types & $\begin{array}{r}\text { Milk } \\
\text { powder }\end{array}$ & Sugar & Flour & $\begin{array}{l}\text { Cocoa } \\
\text { butter }\end{array}$ & $\begin{array}{r}\text { Cocoa } \\
\text { mass }\end{array}$ & Palm oil & $\begin{array}{r}\text { Manufacturing } \\
\text { processes }\end{array}$ & $\begin{array}{r}\text { Primary } \\
\text { packaging }\end{array}$ & $\begin{array}{l}\text { Secondary } \\
\text { packaging }\end{array}$ \\
\hline \multirow[t]{3}{*}{ Freshwater ecotoxicity (FET) } & Moulded chocolates & $19 \%$ & $11 \%$ & & $35 \%$ & $26 \%$ & & & & \\
\hline & Countlines & $21 \%$ & $11 \%$ & & $34 \%$ & $19 \%$ & & & & \\
\hline & Chocolates in bag & $21 \%$ & $11 \%$ & & $34 \%$ & $16 \%$ & & & & \\
\hline \multirow[t]{3}{*}{ Marine ecotoxicity (MET) } & Moulded chocolates & $12 \%$ & $9 \%$ & & $40 \%$ & $30 \%$ & & & & \\
\hline & Countlines & $16 \%$ & $13 \%$ & & $31 \%$ & $23 \%$ & & & & \\
\hline & Chocolates in bag & $13 \%$ & $9 \%$ & & $40 \%$ & $23 \%$ & & & & \\
\hline \multirow[t]{3}{*}{ Terrestrial acidification (TA) } & Moulded chocolates & $90 \%$ & & & & & & & & \\
\hline & Countlines & $83 \%$ & & & & & & & & \\
\hline & Chocolates in bag & $88 \%$ & & & & & & & & \\
\hline \multirow[t]{3}{*}{ Agricaltural land occupation (ALO) } & Moulded chocolates & $76 \%$ & $15 \%$ & & & & & & & \\
\hline & Countlines & $66 \%$ & $17 \%$ & & & & & & & \\
\hline & Chocolates in bag & $73 \%$ & $13 \%$ & & & & & & & \\
\hline \multirow[t]{3}{*}{ Urban land occupation (ULO) } & Moulded chocolates & $51 \%$ & $7 \%$ & & & & & $6 \%$ & & $12 \%$ \\
\hline & Countlines & $37 \%$ & $7 \%$ & $8 \%$ & & & & $10 \%$ & & $11 \%$ \\
\hline & Chocolates in bag & $44 \%$ & $6 \%$ & & & & & $6 \%$ & $9 \%$ & $19 \%$ \\
\hline \multirow[t]{3}{*}{ Natural land transformation (NLT) } & Moulded chocolates & $94 \%$ & & & & & & & & \\
\hline & Countlines & $88 \%$ & & & & & & & & \\
\hline & Chocolates in bag & $92 \%$ & & & & & & & & \\
\hline \multirow[t]{3}{*}{ Mineral depletion (MD) } & Moulded chocolates & $34 \%$ & $6 \%$ & & $23 \%$ & $17 \%$ & & $7 \%$ & & \\
\hline & Countlines & $27 \%$ & $6 \%$ & & $18 \%$ & $13 \%$ & & $13 \%$ & $10 \%$ & \\
\hline & Chocolates in bag & $33 \%$ & & & $20 \%$ & $11 \%$ & & $7 \%$ & $14 \%$ & \\
\hline \multirow[t]{3}{*}{ Water footprint } & Moulded chocolates & $25 \%$ & & & & & & $12 \%$ & $52 \%$ & \\
\hline & Countlines & $12 \%$ & & & & & & $13 \%$ & $64 \%$ & \\
\hline & Chocolates in bag & $13 \%$ & & & & & & $7 \%$ & $69 \%$ & \\
\hline
\end{tabular}




\section{Sensitivity analysis}

Table S-3.1 Loss of ingredients

\begin{tabular}{|c|c|c|c|}
\hline & \multicolumn{3}{|c|}{ Percentage change for $5 \%$ loss relative to the base case } \\
\hline Impact categories & $\begin{array}{r}\text { Moulded } \\
\text { chocolates }\end{array}$ & $\begin{array}{l}\text { Chocolate } \\
\text { countlines }\end{array}$ & Chocolates in bag \\
\hline Primary energy demand (PED) & $4 \%$ & $4 \%$ & $5 \%$ \\
\hline Agricultural land occupation (ALO & $5 \%$ & $5 \%$ & $6 \%$ \\
\hline Global warming potential (GWP) & $4 \%$ & $3 \%$ & $4 \%$ \\
\hline Fossil fuel depletion (FFD) & $3 \%$ & $2 \%$ & $3 \%$ \\
\hline Freshwater ecotoxicity (FET) & $3 \%$ & $3 \%$ & $5 \%$ \\
\hline Freshwater eutrophication (FE) & $3 \%$ & $3 \%$ & $4 \%$ \\
\hline Human toxicity $(\mathrm{HT})$ & $4 \%$ & $4 \%$ & $5 \%$ \\
\hline Marine ecotoxicity (MET) & $2 \%$ & $3 \%$ & $4 \%$ \\
\hline Marine eutrophication (ME) & $5 \%$ & $5 \%$ & $5 \%$ \\
\hline Mineral depletion (MD) & $3 \%$ & $3 \%$ & $4 \%$ \\
\hline Natural land transformation (NLT) & $5 \%$ & $5 \%$ & $5 \%$ \\
\hline Ozone depletion (OD) & $4 \%$ & $3 \%$ & $4 \%$ \\
\hline Photochemical oxidant formation & $4 \%$ & $3 \%$ & $6 \%$ \\
\hline Terrestrial acidification (TA) & $5 \%$ & $5 \%$ & $5 \%$ \\
\hline Terrestrial ecotoxicity (TET) & $4 \%$ & $4 \%$ & $11 \%$ \\
\hline \multirow[t]{2}{*}{ Urban land occupation (ULO) } & $4 \%$ & $3 \%$ & $5 \%$ \\
\hline & \multicolumn{3}{|c|}{ Percentage change for $10 \%$ loss relative to the base case } \\
\hline Impact categories & $\begin{array}{r}\text { Moulded } \\
\text { chocolates }\end{array}$ & $\begin{array}{l}\text { Chocolate } \\
\text { countlines }\end{array}$ & Chocolates in bag \\
\hline Primary energy demand (PED) & $9.0 \%$ & $7.5 \%$ & $11.4 \%$ \\
\hline Agricultural land occupation (ALO & $9.8 \%$ & $9.3 \%$ & $12.0 \%$ \\
\hline Global warming potential (GWP) & $8.6 \%$ & $6.7 \%$ & $8.6 \%$ \\
\hline Fossil fuel depletion (FFD) & $7.1 \%$ & $4.8 \%$ & $7.2 \%$ \\
\hline Freshwater ecotoxicity (FET) & $8.3 \%$ & $7.6 \%$ & $10.3 \%$ \\
\hline Freshwater eutrophication (FE) & $7.7 \%$ & $5.7 \%$ & $7.6 \%$ \\
\hline Human toxicity $(\mathrm{HT})$ & $8.9 \%$ & $7.7 \%$ & $10.8 \%$ \\
\hline Marine ecotoxicity (MET) & $7.4 \%$ & $6.9 \%$ & $9.8 \%$ \\
\hline Marine eutrophication (ME) & $9.8 \%$ & $9.5 \%$ & $10.9 \%$ \\
\hline Mineral depletion (MD) & $7.7 \%$ & $6.2 \%$ & $8.7 \%$ \\
\hline Natural land transformation (NLT) & $9.7 \%$ & $9.0 \%$ & $9.7 \%$ \\
\hline Ozone depletion (OD) & $8.4 \%$ & $6.2 \%$ & $8.6 \%$ \\
\hline Photochemical oxidant formation & $8.4 \%$ & $7.5 \%$ & $12.0 \%$ \\
\hline Terrestrial acidification (TA) & $9.6 \%$ & $9.2 \%$ & $10.1 \%$ \\
\hline Terrestrial ecotoxicity (TET) & $9.0 \%$ & $8.4 \%$ & $23.5 \%$ \\
\hline Urban land occupation (ULO) & $8.5 \%$ & $6.7 \%$ & $10.0 \%$ \\
\hline
\end{tabular}


Table S-3.2 Different data source for cocoa beans cultivation

Percentage change relative to the base case when using data from Ecoinvent V3.3

\begin{tabular}{lrrr}
\hline Impact categories & $\begin{array}{r}\text { Moulded } \\
\text { chocolates }\end{array}$ & $\begin{array}{r}\text { Chocolate } \\
\text { countlines }\end{array}$ & Chocolates in bag \\
\hline Primary energy demand (PED) & $72 \%$ & $50 \%$ & $51 \%$ \\
Agricultural land occupation (ALO & $245 \%$ & $197 \%$ & $176 \%$ \\
Global warming potential (GWP) & $23 \%$ & $11 \%$ & $58 \%$ \\
Fossil fuel depletion (FFD) & $34 \%$ & $14 \%$ & $26 \%$ \\
Freshwater ecotoxicity (FET) & $7 \%$ & $1 \%$ & $1 \%$ \\
Freshwater eutrophication (FE) & $111 \%$ & $61 \%$ & $77 \%$ \\
Human toxicity (HT) & $110 \%$ & $57 \%$ & $74 \%$ \\
Marine ecotoxicity (MET) & $-10 \%$ & $-12 \%$ & $-14 \%$ \\
Marine eutrophication (ME) & $146 \%$ & $125 \%$ & $101 \%$ \\
Mineral depletion (MD) & $58 \%$ & $42 \%$ & $43 \%$ \\
Natural land transformation (NLT) & $3725 \%$ & $3437 \%$ & $2511 \%$ \\
Ozone depletion (OD) & $136 \%$ & $88 \%$ & $98 \%$ \\
Photochemical oxidant formation & $101 \%$ & $68 \%$ & $73 \%$ \\
Terrestrial acidification (TA) & $9 \%$ & $6 \%$ & $8 \%$ \\
Terrestrial ecotoxicity (TET) & $37 \%$ & $27 \%$ & $29 \%$ \\
Urban land occupation (ULO) & $143 \%$ & $87 \%$ & $114 \%$ \\
\hline
\end{tabular}




\begin{tabular}{|c|c|c|c|}
\hline \multirow[b]{2}{*}{ Impact categories } & \multicolumn{3}{|c|}{ Percentage change for $2 \%$ loss relative to the base case } \\
\hline & Moulded chocolates & Chocolate countlines & Chocolates in bag \\
\hline Primary energy demand (PED) & $0.21 \%$ & $0.12 \%$ & $0.17 \%$ \\
\hline Agricultural land occupation (ALO) & $0.11 \%$ & $0.12 \%$ & $0.18 \%$ \\
\hline Global warming potential (GWP) & $0.12 \%$ & $0.08 \%$ & $0.11 \%$ \\
\hline Fossil fuel depletion (FFD) & $0.00 \%$ & $0.00 \%$ & $0.00 \%$ \\
\hline Freshwater ecotoxicity (FET) & $0.04 \%$ & $0.03 \%$ & $0.05 \%$ \\
\hline Freshwater eutrophication (FE) & $0.24 \%$ & $0.09 \%$ & $0.13 \%$ \\
\hline Human toxicity $(\mathrm{HT})$ & $0.12 \%$ & $0.07 \%$ & $0.10 \%$ \\
\hline Marine ecotoxicity (MET) & $0.05 \%$ & $0.03 \%$ & $0.05 \%$ \\
\hline Marine eutrophication (ME) & $0.02 \%$ & $0.02 \%$ & $0.02 \%$ \\
\hline Mineral depletion (MD) & $0.14 \%$ & $0.10 \%$ & $0.14 \%$ \\
\hline Natural land transformation (NLT) & $0.02 \%$ & $0.02 \%$ & $0.03 \%$ \\
\hline Ozone depletion (OD) & $0.19 \%$ & $0.13 \%$ & $0.19 \%$ \\
\hline Photochemical oxidant formation (PC & $0.11 \%$ & $0.09 \%$ & $0.12 \%$ \\
\hline Terrestrial acidification (TA) & $0.02 \%$ & $0.02 \%$ & $0.02 \%$ \\
\hline Terrestrial ecotoxicity (TET) & $0.01 \%$ & $0.01 \%$ & $0.02 \%$ \\
\hline \multirow[t]{2}{*}{ Urban land occupation (ULO) } & $0.30 \%$ & $0.24 \%$ & $0.40 \%$ \\
\hline & \multicolumn{3}{|c|}{ Percentage change for $5 \%$ loss relative to the base case } \\
\hline Impact categories & Moulded chocolates & Chocolate countlines & Chocolates in bag \\
\hline Primary energy demand (PED) & $0.00 \%$ & $0.29 \%$ & $0.42 \%$ \\
\hline Agricultural land occupation (ALO) & $0.26 \%$ & $0.29 \%$ & $0.45 \%$ \\
\hline Global warming potential (GWP) & $0.14 \%$ & $0.19 \%$ & $0.26 \%$ \\
\hline Fossil fuel depletion (FFD) & $0.01 \%$ & $0.01 \%$ & $0.01 \%$ \\
\hline Freshwater ecotoxicity (FET) & $0.05 \%$ & $0.07 \%$ & $0.12 \%$ \\
\hline Freshwater eutrophication (FE) & $0.20 \%$ & $0.21 \%$ & $0.32 \%$ \\
\hline Human toxicity $(\mathrm{HT})$ & $0.14 \%$ & $0.16 \%$ & $0.26 \%$ \\
\hline Marine ecotoxicity (MET) & $0.05 \%$ & $0.07 \%$ & $0.12 \%$ \\
\hline Marine eutrophication (ME) & $0.03 \%$ & $0.04 \%$ & $0.06 \%$ \\
\hline Mineral depletion (MD) & $0.17 \%$ & $0.24 \%$ & $0.34 \%$ \\
\hline Natural land transformation (NLT) & $0.04 \%$ & $0.05 \%$ & $0.07 \%$ \\
\hline Ozone depletion (OD) & $0.26 \%$ & $0.31 \%$ & $0.47 \%$ \\
\hline Photochemical oxidant formation (PC & $0.15 \%$ & $0.21 \%$ & $0.29 \%$ \\
\hline Terrestrial acidification $(\mathrm{TA})$ & $0.02 \%$ & $0.04 \%$ & $0.05 \%$ \\
\hline Terrestrial ecotoxicity (TET) & $0.03 \%$ & $0.03 \%$ & $0.06 \%$ \\
\hline \multirow[t]{2}{*}{ Urban land occupation (ULO) } & $0.62 \%$ & $0.58 \%$ & $0.98 \%$ \\
\hline & \multicolumn{3}{|c|}{ Percentage change for $5 \%$ loss relative to the base case } \\
\hline Impact categories & Moulded chocolates & Chocolate countlines & Chocolates in bag \\
\hline Primary energy demand (PED) & $0.45 \%$ & $0.56 \%$ & $0.80 \%$ \\
\hline Agricultural land occupation (ALO) & $0.49 \%$ & $0.54 \%$ & $0.85 \%$ \\
\hline Global warming potential (GWP) & $0.27 \%$ & $0.36 \%$ & $0.49 \%$ \\
\hline Fossil fuel depletion (FFD) & $0.01 \%$ & $0.01 \%$ & $0.02 \%$ \\
\hline Freshwater ecotoxicity (FET) & $0.10 \%$ & $0.13 \%$ & $0.22 \%$ \\
\hline Freshwater eutrophication (FE) & $0.38 \%$ & $0.41 \%$ & $0.61 \%$ \\
\hline Human toxicity $(\mathrm{HT})$ & $0.27 \%$ & $0.31 \%$ & $0.49 \%$ \\
\hline Marine ecotoxicity (MET) & $0.10 \%$ & $0.14 \%$ & $0.22 \%$ \\
\hline Marine eutrophication (ME) & $0.06 \%$ & $0.08 \%$ & $0.11 \%$ \\
\hline Mineral depletion (MD) & $0.32 \%$ & $0.46 \%$ & $0.64 \%$ \\
\hline Natural land transformation (NLT) & $0.07 \%$ & $0.09 \%$ & $0.13 \%$ \\
\hline Ozone depletion (OD) & $0.50 \%$ & $0.59 \%$ & $0.89 \%$ \\
\hline Photochemical oxidant formation (PC & $0.29 \%$ & $0.40 \%$ & $0.55 \%$ \\
\hline Terrestrial acidification (TA) & $0.05 \%$ & $0.08 \%$ & $0.09 \%$ \\
\hline Terrestrial ecotoxicity (TET) & $0.05 \%$ & $0.06 \%$ & $0.11 \%$ \\
\hline Urban land occupation (ULO) & $1.17 \%$ & $1.12 \%$ & $1.86 \%$ \\
\hline
\end{tabular}


Table S-4 Improvement opportunities: manure composting and $20 \%$ energy reduction in the milk $p$ Impact categories lange relative to the base case for moulded chocolates ${ }^{\mathbf{a}}$

Primary energy demand (PED) $-2 \%$

Agricultural land occupation (ALO)

Global warming potential (GWP)

$-12 \%$

Fossil Fuel depletion (FFD)

$-5 \%$

Freshwater ecotoxicity (FET)

$2 \%$

Freshwater eutrophication (FE)

$-4 \%$

Human toxicity (HT)

$-1 \%$

Marine ecotoxicity (MET)

$1 \%$

Marine eutrophication (ME)

$0 \%$

Metal depletion (MD)

$-2 \%$

Natural land transformation (NLT)

$0 \%$

Ozone depletion (OD)

$-1 \%$

Photochemical oxidant formation (F $\quad-2 \%$

Terrestrial acidification (TA) $-1 \%$

Terrestrial ecotoxicity (TET) $-1 \%$

Urban land occupation (ULO)

$0 \%$

\begin{tabular}{lr}
\hline Impact categories & ange relative to the base case for chocolate countlines \\
\hline Primary energy demand (PED) & $-1 \%$ \\
Agricultural land occupation (ALO) & $0 \%$ \\
Global warming potential (GWP) & $-9 \%$ \\
Fossil Fuel depletion (FFD) & $-3 \%$ \\
Freshwater ecotoxicity (FET) & $2 \%$ \\
Freshwater eutrophication (FE) & $-3 \%$ \\
Human toxicity (HT) & $-1 \%$ \\
Marine ecotoxicity (MET) & $1 \%$ \\
Marine eutrophication (ME) & $0 \%$ \\
Metal depletion (MD) & $-1 \%$ \\
Natural land transformation (NLT) & $-1 \%$ \\
Ozone depletion (OD) & $-1 \%$ \\
Photochemical oxidant formation (F & $-1 \%$ \\
Terrestrial acidification (TA) & $-1 \%$ \\
Terrestrial ecotoxicity (TET) & $0 \%$ \\
Urban land occupation (ULO) & $0 \%$ \\
\hline
\end{tabular}

\begin{tabular}{lr}
\hline Impact categories & Change relative to the base case for chocolates in $\mathbf{b a g}^{\mathbf{a}}$ \\
\hline Primary energy demand (PED) & $-2 \%$ \\
Agricultural land occupation (ALO) & $0 \%$ \\
Global warming potential (GWP) & $-11 \%$ \\
Fossil Fuel depletion (FFD) & $-5 \%$ \\
Freshwater ecotoxicity (FET) & $2 \%$ \\
Freshwater eutrophication (FE) & $-4 \%$ \\
Human toxicity (HT) & $-1 \%$ \\
Marine ecotoxicity (MET) & $2 \%$ \\
Marine eutrophication (ME) & $-1 \%$ \\
Metal depletion (MD) & $-1 \%$ \\
Natural land transformation (NLT) & $-1 \%$ \\
Ozone depletion (OD) & $-2 \%$ \\
Photochemical oxidant formation (F & $-2 \%$ \\
Terrestrial acidification (TA) & $-1 \%$ \\
Terrestrial ecotoxicity (TET) & $-1 \%$ \\
Urban land occupation (ULO) & $0 \%$ \\
\hline a Negative valos repros
\end{tabular}

\footnotetext{
${ }^{a}$ Negative values represent a reduction and positive an increase in impacts.
} 